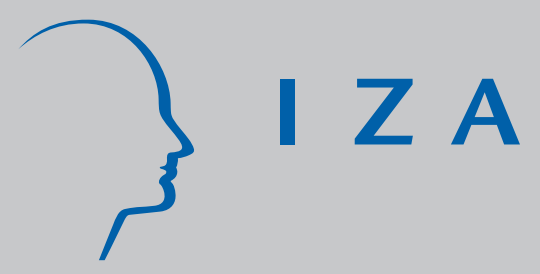

IZA DP No. 351

Gross J ob Flows in Russian Industry Before and After Reforms: Has Destruction Become More Creative?

J. David Brown

J ohn S. Earle

August 2001 


\title{
Gross Job Flows in Russian Industry Before and After Reforms: Has Destruction Become More Creative?
}

\author{
J. David Brown \\ SITE, Stockholm School of Economics, \\ Central European University \\ John S. Earle \\ SITE, Stockholm School of Economics, \\ Central European University and IZA, Bonn
}

Discussion Paper No. 351
August 2001

\author{
IZA \\ P.O. Box 7240 \\ D-53072 Bonn \\ Germany \\ Tel.: +49-228-3894-0 \\ Fax: +49-228-3894-210 \\ Email: iza@iza.org
}

This Discussion Paper is issued within the framework of IZA's research area Labor Markets in Transition. Any opinions expressed here are those of the author(s) and not those of the institute. Research disseminated by IZA may include views on policy, but the institute itself takes no institutional policy positions.

The Institute for the Study of Labor (IZA) in Bonn is a local and virtual international research center and a place of communication between science, politics and business. IZA is an independent, nonprofit limited liability company (Gesellschaft mit beschränkter Haftung) supported by the Deutsche Post AG. The center is associated with the University of Bonn and offers a stimulating research environment through its research networks, research support, and visitors and doctoral programs. ZA engages in (i) original and internationally competitive research in all fields of labor economics, (ii) development of policy concepts, and (iii) dissemination of research results and concepts to the interested public. The current research program deals with (1) mobility and flexibility of labor markets, (2) internationalization of labor markets and European integration, (3) the welfare state and labor markets, (4) labor markets in transition, (5) the future of work, (6) project evaluation and (7) general labor economics.

IZA Discussion Papers often represent preliminary work and are circulated to encourage discussion. Citation of such a paper should account for its provisional character. 


\section{ABSTRACT \\ Gross Job Flows in Russian Industry Before and After Reforms: Has Destruction Become More Creative*}

This paper uses 1985-1999 manufacturing census data for old Russian enterprises to calculate the magnitude and productivity effects of gross job flow rates before and after reforms. Job creation was low throughout the period in this sector, but increased slightly during the transition, while job destruction rose markedly. Heterogeneity in firm employment change also increased significantly. Intra- and inter-sectoral job reallocation had no effect on aggregate labor productivity during the socialist period, while they have made a strong positive contribution during the transition. Privatization and product market competition have not led to greater job destruction overall, but rather have helped to focus the destruction in the firms with the lowest productivity.

JEL Classification: E24, J63, O47, P23

Keywords: Job destruction, job reallocation, productivity, transition, Russia

John S. Earle

SITE

Stockholm School of Economics

Sveavägen 65, P.O. Box 6501

SE-11383 Stockholm

Sweden

Tel.: +46-8-736-9680

Fax: +46-70-578-7899

Email: John.Earle@hhs.se

\footnotetext{
* We thank Klara Sabirianova for data advice, Mark Schaffer for helpful comments, Georgy Artermov for assistance, and the MacArthur Foundation and the Bank of Sweden for financial support. Contact information: david.brown@hhs.se, john.earle@hhs.se, Central European University Department of Economics, Nador utca 9, $\mathrm{H}-1051$ Budapest, Hungary.
} 


\section{INTRODUCTION}

Is Russia restructuring? While it is evident from a variety of sources that a phenomenal number of jobs have been destroyed in the Russian economy since radical reforms began, much less is known about the character of this process: Is it Schumpeterian "creative destruction," weeding out the least efficient jobs and making way for reallocation to more productive uses? Or instead is the job destruction simply destructive, reflecting either indiscriminate collapse throughout the economy or, even worse, a concentration in firms and sectors of relatively high productivity? The possibility of "schlerosis" could be quite real in Russia, where governments may protect weak firms, where profitable companies are subject to public and private predation, and where stripping of assets is practically a national sport.

In this paper we analyze gross job flows in Russian industry using nearly comprehensive data on large and medium-size manufacturing firms with annual observations over the period 1985-99. While our data, like those available for most countries including those of Eastern Europe and the former Soviet Union, do not lend themselves to a complete quantification of all job flows, they are well-suited to a study of the job reallocation process in the old industrial sector that was built up during the socialist period. The behavior of this sector is also of particular interest in Russia and other transition economies, where socialist planning resulted in a large concentration of capital and skilled labor and where the price, technology and competition shocks of transition have been particularly severe.

Following the methodology developed by Davis and Haltiwanger (1992 and 1999), we quantify the rates of job destruction, creation, reallocation and excess reallocation for this sector. To study the impact of reforms, we examine whether the patterns changed over the 15year time period of our data, asking whether behavior has begun to resemble more closely that of market economies; in some analyses we treat the "big-bang" liberalization of 1992 as the 
dividing line between what we, for simplicity, refer to as "pre-reform" and "post-reform" periods. ${ }^{1}$ We also analyze the persistence in job flows and the heterogeneity within and across groups of firms, defined according to industry, region, size, ownership, product market concentration, import penetration, exports, labor market concentration, capital intensity, electricity intensity, average wage, and labor productivity. Again, our interest is in whether economic reforms have produced patterns of job flows more akin to market economies, a purpose for which our panel data are well-suited.

Besides measuring the patterns of job flows in the old industrial sector in Russia, the most important contribution of our work is an analysis of the impact of job flows on productivity change. We extend decomposition techniques used in Foster, Haltiwanger and Krizan (1998) and elsewhere, enabling us to distinguish sources of aggregate productivity change: employment reallocation across industries, employment reallocation between firms within industries, average within-firm productivity growth, and covariance terms capturing the co-movements among these components. The purpose of the decompositions is to capture the contribution of job flows to productivity and therefore permit an assessment of whether reallocation has become more productive since reforms began.

Our work builds not only on the already cited seminal works of Davis and Haltiwanger and others writing on market economies, but also a considerable number of articles on gross job flows in transition economies. Among these articles are Konings, Lehmann and Schaffer (1996), Bilsen and Konings (1998), Faggio and Konings (1999), Haltiwanger and Vodopivec (2000), Acquisti and Lehmann (2000), and others. This research has already documented a number of important patterns in transition economies: the rise in job and worker flows associated with reforms, the rise in the proportion of worker flows associated with job flows, the rise in job destruction leading that in job creation, the dominant role of small firms

\footnotetext{
${ }^{1}$ Some partial reforms started from 1988 during the perestroika period, and our analysis of annual data permits us to detect changes during this period, but these reforms were dwarfed by those in 1992 .
} 
(generally new private start-ups) in job creation and of large firms (generally privatized and state-owned enterprises) in job destruction, and the relatively large role played by intersectoral shifts in excess job reallocation.

We employ our Russian data to examine these and other empirical regularities. Compared to the data used in the previous studies, our data have the advantage of covering a much longer time span, reaching far back into the socialist period, and including essentially the entire "old" sector of firms inherited from the socialist period. On the other hand, we are unable to reliably track exit and entry nor to measure flows in the dynamic small firm sector. Due to these data limitations, we focus our efforts on addressing the nature of the job allocation process in the old sector, in particular investigating the degree to which job flows are productivity enhancing or whether they suggest "schlerosis" in the sense of Caballero and Hammour (2000), whereby unproductive firms survive due to market imperfections and government policies. None of the previous studies of transition economies examines the productivity consequences of job flows, a major gap in a literature attempting to understand the role of labor markets in facilitating economic restructuring.

The rest of the paper is organized as follows. Section 2 provides an overview of aggregate labor market developments in Russian industry, including official statistics on employment, output, productivity and worker turnover. Section 3 presents our measurement of job reallocation in the old sector, including the degree of persistence and heterogeneity of job flows and firm growth, decompositions of excess job reallocation within and between groups of firms, and the relationship of job and worker flows. In Section 4, we examine the relationship of job reallocation with employer characteristics in a more detailed way, focussing on size, ownership, capital and electricity intensity, average wage, labor productivity, product and labor market concentration, import penetration, and exporting behavior. Section 5 is 
devoted to the relationship between job flows and productivity. Section 6 concludes, and the data are described in the Appendix.

\section{LABOR MARKET DEVELOPMENTS IN RUSSIAN INDUSTRY}

This section presents an overview of the aggregate trends in the Russian industrial labor market. We rely on official information from the Russian State Statistical Committee (Goskomstat) on output, employment, productivity, and worker turnover. Although the series are subject to measurement error and interpretational dispute, they are adequate for describing the basic context in which our measurements of job flows, presented in subsequent sections of the paper, may be understood.

We start with an analysis at the aggregate industry level and then consider disaggregation across industries. Figure 1 shows the evolution of industrial production, employment, and labor productivity in Russia from 1985 to 1999 . While both the officially reported growth in output during the late 1980s and drastic decline in the early 1990s must be taken somewhat cautiously, the broad trends are well-accepted. In particular, the "output shock," although experienced by all transition economies to some extent, was especially severe in Russia, where official industrial production fell by more than 50 percent in just the first four years of the 1990s. Employment decline was also quite drastic by international and historical standards, falling by nearly 40 percent by 1998 . Nevertheless, the drop in employment was more gradual than that of output, resulting in a large decline in labor productivity as well.

Even subject to large caveats due to measurement problems, the aggregate data show a clear picture of an industrial sector in deep depression during the 1990s. This already suggests that job destruction dominates job creation, which we also verify with our micro-data later on. But it still raises the question of the nature of the decline. The excessive priority attached to

\footnotetext{
2 The measurement issues have been extensively discussed; see for instance Ofer (1987) for the Soviet period, Cochrane and Ickes (1995) for the early transition years, and Fischer and Sahay (2000) for the more recent period.
} 
industrialization, particularly to the heavy industrial sectors and to large prestigious projects, implies that over-production and over-employment should fall under market forces. Perhaps the de-industrialization we are observing in Russia is ridding the economy of its over-built, inefficient elements in a process of Schumpeterian creative destruction. On the other hand, the aggregate industrial decline may reflect a depression in which all economic activity declines simultaneously and roughly proportionately. A final possibility is that the decline is actually more severe in the more productive sectors of the economy, suggesting schlerosis in an excessive preservation of inefficient jobs and unhealthy pressures on more productive firms and sectors. This possibility could be quite real in Russia, where government may protect weak firms, where profitable companies are subject to public and private predation, and where stripping of assets is practically a national sport.

A first approach to understanding the nature of industrial decline in Russia is to disaggregate, again using official statistics. Figure 2 shows the output evolution for 11 industrial sectors. After a very stable period in the late 1980s, industrial production fell in the 1990s in every one of these branches. Still more striking is the increase in heterogeneity, as the declines vary from a maximum of nearly 90 percent in textiles to about 25 percent in electricity production. Clearly the magnitude of the shock has been non-uniform across sectors.

The employment changes in Figure 3 display a similar pattern of initial stability and homogeneity but became even more diverse in the 1990s, with substantial growth in electricity, little change in fuels and non-ferrous metallurgy, and large declines in textiles, machinery and wood and paper. Again, the data display substantial heterogeneity. Even from these aggregate indicators, it appears we can reject the notion that industrial decline in Russia merely reflects an aggregate demand shock with homogeneous effects across sectors.

How are these output and employment changes reflected in productivity? Figure 1 showed that aggregate industrial productivity has fallen since 1989, but this could be due either 
to labor hoarding in the face of demand shocks, or it could reflect compositional effects associated with differential relative rates of decline. A disaggregation of aggregate productivity across the 11 industrial branches is provided in Figure 4. Since 1990/91, productivity has fallen in all the sectors, but for reasons that differ. In some sectors, the productivity decline is associated with an unusually sharp output shock, in some the output shock is about average but employment declines relatively little, and in others the output shock is small but employment declines little if at all. This suggests that both compositional and behavioral forces are at work: changes in productivity are quite heterogeneous and they may be associated with changes in composition; and labor hoarding behavior may account for some of the observed patterns, but even at this aggregate level is insufficient to explain all of them.

A final stylized fact to motivate our analysis of the micro-data on job flows concerns worker flows, shown in Table 1. From 1992 to 1998, the period for which Goskomstat data are available to us, annual hiring rates are remarkably high, ranging from 19 to 24 percent of average employment for each year. Separation rates are closer to 30 percent. The high rate of worker turnover in Russia, and its relative constancy over the pre-transition and transition periods has previously been remarked by Yemtsov (1994), Commander et al. (1995), Layard and Richter (1995), and Gimpelson and Lippoldt (1996). These empirical regularities have also been verified in independent firm surveys, as reported in Kapeliushnikov (1996), Earle and Sabirianova (2001), and Biletsky et al. (2001). The behavior is an abiding puzzle about Russian labor markets, especially when considered jointly with the many factors - sharp demand shocks, a rise in unemployment, worker ownership, barriers to mobility, wage arrears, poor information - that would tend to reduce worker turnover.

And the Russian pattern is somewhat at odds with the behavior found in other countries. Earle and Oprescu (1995), for instance, use official reports on aggregate labor flows in Romania from 1982 through 1992 and find, after a sharp increase in both hiring and 
separation rates in 1990 ( 21 and 24 percent, respectively), a sharp drop in hiring to 9 percent in 1991 and 5 percent 1992, while separations remain above the pre-1990 level. Haltiwanger and Vodopivec (2000) use Estonian Labor Force Survey data (including retrospective information from 1989-94) and find gradually increasing turnover in the early 1990s, but the manufacturing hiring rate estimated for 1992, 14.4 percent, is still substantially lower than the Russian rate for the same year. Using a similar methodology, Jurajda and Terrell (2001) find roughly constant hiring and separation rates in the Czech state sector from 1991 to 1996; the approximate 15 percent rate for the former and 20 percent for the latter are again less than the Russian rates. As their data start in 1991, we cannot know whether these differ from those of the past.

\section{JOB REALLOCATION IN THE OLD SECTOR}

The aggregate evidence, reported in the previous section, suggests that there may be high returns to disaggregating the analysis to the micro level, in order to understand the flows better. In this section, we report the results from measuring job flow rates using an enterprise panel data set with annual observations on Russian industrial firms from 1985 to 1999 . The data, which are described in the Appendix, contain nearly the entire "old" sector inherited from the socialist period, and indeed they are likely to contain few if any newly created start-up firms. The main reason for this is that we observe only firms with at least 100 employees or owned at least 25 percent by a legal entity. As new private start-ups are likely to be small and individually or family-owned, most if not all of them will be excluded from the sample. A final note is that our data pertain to firms, not establishments; this may confound some comparisons with data from other countries, for instance the U.S.

Table 2 contains our calculations of job flow rates by year, following the definitions in Davis and Haltiwanger $(1992,1999)$. The net change figures show that industry began to contract already in the late 1980's. The creation rate is low in all years, although it increases 
slightly after 1991 , the annual average rising from 1.4 to 2.4 percent. The destruction rate is quite low between 1985-1987, begins to pick up during the early Perestroika period of 19881990, and then jumps up in 1991, the year when the first major price adjustments took place. It remains high throughout the post-reform period (the period after price liberalization, which occurred on January 2, 1992), approaching or even exceeding typical destruction rates in the US; since the latter figures are calculated for establishments rather than firms, it seems clear that job destruction in Russia is higher. As a consequence, post-reform reallocation rates are more than double the pre-reform rates, as are the rates of net decline. Excess reallocation also rises considerably.

These data provide evidence of behavioral change associated with transition, but the big change driving all the others in the firms we can observe is the rise in job destruction. The main purpose of this paper, therefore, is to investigate the nature of the massive job destruction, whether it appears to be creative in weeding out lower productivity jobs while permitting the healthier, higher productivity sort to survive, or whether it is simply destructive in reducing employment indiscriminately or even in concentrating on the most productive jobs in the sector. We will return to this question below, while for the moment we focus on quantifying some important dimensions of the job reallocation process.

A first issue is persistence. Are the job creation and destruction flows persistent in the sense that jobs added to or subtracted from a firm tend to remain gained or lost in future years? Table 3 provides some evidence on this issue. We find a high rate of creation, destruction, and reallocation persistence in both the socialist and reform periods. The rates are close to those calculated by Davis and Haltiwanger (1999) for the U.S., though destruction persistence is even higher than in the U.S. Job flows in Russia are not primarily temporary phenomena.

A second issue is heterogeneity. Table 4 contains percentiles of the distribution of employment growth rates. We find that the mean is negative in every year except 1987 and 
that the magnitude of the decline increases through most of the sample period. The distribution was quite concentrated under socialism, with half the firms falling between growth rates of -2.4 percent and 1.6 percent in 1985-86. The distribution widened somewhat and turned more negative during the Perestroika period, and then started to become much more dispersed in 1991. The standard deviation of the growth rate more than doubled over the period, going from 13.8 in $1985-86$ to 29.6 in $1998-99$. The range of the distribution widens considerably: at the $5^{\text {th }}$ percentile declining from about minus 13 to about minus 53 percent, and at the $95^{\text {th }}$ percentile from around plus 14 to about 29 percent. Clearly heterogeneity is substantial and rising through this period.

Further documenting the increasing heterogeneity, the variation of job flow rates by region and industry for the pre-reform period of 1985-91 and post-reform period of 1991-99 is presented in Table 5. Variation in job creation rates shows little change, but the standard deviation of destruction rates across both regions (78 in this analysis) and industries (264 at the 5-digit OKONKh level) more than doubles. The variation in reallocation, net changes and excess reallocation all rise substantially, but clearly this is due to the increased variance of destruction, not of creation.

Another way to view heterogeneity is to decompose the share of excess job reallocation due to employment shifts across groups of firms from that due to shifts within groups (Davis and Haltiwanger, 1992). For this purpose, "groups" can be defined in a variety of ways, and Table 6 shows eight alternative groupings. As in Davis and Haltiwanger (1992), we find that most excess job reallocation occurs within groups, even when very narrowly defined. At one extreme, when we cross 2-digit industries by regions and size categories to get more than 2000 cells and an average cell size of between 7 and 8, still more than half the excess job flows are within the cells rather than between them: 56 percent during the 1985-91 period and 68 percent over 1991-99. 
This rise in the within share does not hold for every possible grouping, however. For instance, if we look only at industry categories, the data show a substantial rise in the between share. This is consistent with the view that interindustry reallocation is an important component of labor market restructuring in transition economies, as reported by Earle (1997) and Sorm and Terrell (2000). The behavior of groups defined by size categories appears to differ, however. The between share for 2-digit industries crossed with size categories (43 cells for 1985-91 and 45 for 1991-99) shows a decline from the pre-reform to post-reform period, implying that more excess reallocation takes place within size categories. It should be noted, however, that these between shares (with groups defined by size and 2-digit industries) are low in both periods.

The final analysis in this section considers the relationship between job and employee flows. As reported in the previous section, hiring rates have been surprisingly high during the post-reform period. To investigate to what extent the hiring is due to job creation, we present disaggregated job flows by 2-digit industry matched up with the employee flows reported by the Goskomstat for the 1994-99 period in Table 7. We calculate the proportion of employee flows accounted for by job flows for each industry separately. 目 In most sectors, job creation accounts for only a small fraction of all hires: the mean is 0.132 for all industry. Only in growing sectors (or those not declining as rapidly as most industries) is the proportion large, particularly in subdivisions of the fuel sector. The proportion of separations accounted for by destruction is somewhat larger - on average equal to 0.371 - with a roughly reverse ordering of industries relative to the create/hires ratio. Thus, little of the hiring can be accounted for by job creation; most is due to churning.

Overall, the data support the propositions that job destruction dominates job flows, that destruction has increased post-reform, that it varies substantially across and within industries,

\footnotetext{
${ }^{3}$ Here we include electricity, extraction, and other non-manufacturing industries so as to be comparable to the employee flows data.
} 
and that it accounts for a large fraction of all separations in the old industrial sector. By contrast, job creation is weak in this sector, despite having increased slightly since reforms began, and much hiring occurs that is of the replacement variety. The next section explores the heterogeneity of job flows according to a number of important employer characteristics, while the next-but-one focuses on the relationship between job flows and productivity.

\section{JOB FLOWS BY EMPLOYER CHARACTERISTICS}

Davis and Haltiwanger (1992, 1999) and Davis, Haltiwanger, and Schuh (1996) (hereafter DHS) describe the variation in job flows in the U.S. by a number of employer characteristics, including size, capital and energy intensity, import penetration, export orientation, average wage, and labor productivity. In this section, we conduct a similar analysis, adding to this list of variables ownership (aggregated state versus nonstate, and disaggregated categories of each) and product and labor market concentration. These latter factors are particularly interesting in the transition setting, as they represent the outcomes of policies of privatization and liberalization; thus, we are interested in how those policies have affected job flows. The section begins by following the approach of Davis and Haltiwanger (1992) and DHS, describing the magnitude of Russian job flows by these firm-level characteristics. In order to assess behavioral changes associated with the reforms, we present results for the 1985-91 and 1991-99 periods separately. To examine the robustness of the relationships when controlling for other factors and to assess the statistical significance of our findings, we also report regressions where firm growth and predicted excess job reallocation are dependent variables and these characteristics are included as independent variables; the impact of reforms is assessed by including interaction terms with a "reform" (1991-99) dummy variable. 
Table 8 presents the descriptive analysis, while Tables 9 and 10 contain the results from estimating equations in which employment growth and predicted excess job reallocation are dependent variables. Note that since net employment change is highly correlated with job destruction and excess job reallocation is highly correlated with job creation in these data, employment growth and excess job reallocation can be interpreted as essentially being the same as job destruction and creation, respectively. In addition to the variables presented (except electricity intensity), ${ }^{\text {G }}$ we also control for fixed industry-territory effects and year dummies in the employment growth regressions. Predicted excess job reallocation is defined as in Davis and Haltiwanger (1999): the difference between the firm's predicted absolute growth rate and the absolute value of the firm's predicted growth rate. The employment growth regressions used to obtain predicted values of growth and absolute growth contain the export dummy, log of average employment over the entire period, year dummies, and industryterritory fixed effects.

We start by examining size, defined by employment categories. A key finding in Western studies (Davis and Haltiwanger, 1992) is that size is negatively associated with both job creation and job destruction. In the transition context, large firms emerging from the central planning system may be more likely to require downsizing, but they also face higher political opposition to reducing employment, so the expected relationship between job destruction and size is ambiguous. The descriptive results in Table 8 are consistent with the findings in both transition and developed market economies that smaller firms are much more dynamic creators of jobs. We also find, however, that large and small firms are destroying jobs at a similar rate. These findings are supported by our regression analysis. The employment

\footnotetext{
${ }^{4}$ We do not include electricity intensity in the regressions in Tables 9 and 10. Since it is observed only in 1993, this greatly reduces the number of observations in the regressions. For the employment growth regression when including electricity intensity, we find that the coefficient on electricity intensity is insignificant, while its interaction with the post-reform dummy is positive and significant at the 5 percent significance level. It is negative and highly significant in the excess job reallocation regression, and the interaction with the post-reform dummy is also negative and highly significant.
} 
growth regression shows that larger firms shed more jobs prior to reform, while smaller firms shed nearly as many post-reform. 5

The ownership dimension is particularly important in transition economies, as it represents the outcome, to a considerable extent, of explicit privatization policies intended to facilitate enterprise restructuring through improved corporate governance. In Russia the industrial sector was privatized through several methods, including lease-buyouts starting in 1990, voucher privatization from November 1992 to July 1994, followed by sales of blocks of shares (Earle and Estrin (1997) provide a description). Here we can evaluate the impact of ownership change on one type of restructuring, namely job flows. For the purpose of a beforeand-after comparison of firms by ownership type, we apply the Goskomstat ownership classifications for 1994, the year by which most privatization occurred, to firms throughout the entire period of 1985-99. This permits us to detect selection bias in the nature of ownership change by examining differences in behavior prior to the date of the change (unfortunately we do not observe the precise date, but we use the 1991-92 dividing line as a rough approximation).

We first restrict the comparison to state versus non-state ownership forms and then consider disaggregated forms of non-state ownership. The results in Table 8 with respect to the former use two different samples, one including all firms and another restricting the sample to firms with complete employment records so as to avoid spurious changes associated with inconsistent samples in the two periods. State firms display a slightly larger job destruction rate in both periods. Otherwise, there is little difference between state and non-state behavior either before or after. A disaggregated analysis according to ownership type shows, in the next panel of Table 8 , that firms that remained municipally owned in the post-reform period have

\footnotetext{
${ }^{5}$ Though not reported in the Table, we also estimated an excess job reallocation regression including average wage, product market and labor market concentration in the first stage rather than size and exports, and in the resulting excess job reallocation regression we find that size is negatively associated with job creation, especially post-reform.
} 
the largest job creation and destruction rates in the pre-reform period, followed by public organizations. In contrast, foreign joint ventures have the largest job creation and reallocation rates in the post-reform period.

The results of the regression analysis are consistent in finding that firms remaining state-owned tend to have a larger job destruction rate both pre- and post-reform, but that privatization itself does not significantly affect this relationship. The results with disaggregated ownership show that it is firms that later become 100 percent private, and also to some extent foreign joint ventures, that exhibit higher employment growth rates in the prereform period; other categories' growth rates are not significantly different from that of federal state-owned enterprises. Only the relationship between foreign joint ventures and employment growth changes significantly (positively) in the post-reform period. This result may be due to the fact that since most foreign joint ventures entered only during the post-reform period, the regression may not sufficiently control for selection bias in this case. ${ }^{6}$ Unlike the descriptive results, the regression results suggest that privatized firms have created jobs less actively, especially post-reform. Partial privatization (the mixed ownership category) in particular appears to be associated with lower job creation. Municipal state-owned enterprises have the highest propensity to create jobs in the post-reform period, followed by regional state-owned enterprises, foreign joint ventures, and public organizations. In sum, the results suggest that selection of firms for privatization was a non-random process, and the ownership change itself appears to be negatively associated with job creation, but unrelated to job destruction.

Competition could also pressure firms to restructure, in which case one would expect to see a greater increase in job creation and destruction among firms facing more competition once markets are liberalized. To investigate this issue, we employ four measures of exposure to competition, including domestic product market concentration, the import penetration ratio,

\footnotetext{
${ }^{6}$ When we employ firm fixed effects, the coefficient on foreign joint ventures is insignificant.
} 
exporting, and labor market concentration. Starting with domestic product market concentration, our measure follows Brown and Earle (2001) in order to take into account different geographic market sizes across industries. We use data at two geographic levels: national and regional. is reflected in the degree to which producers in the industry are located across different regions of the country. For instance, an industry with member firms in all regions is likely to be characterized by regional markets, and an industry with firms in only a few regions is likely to be a national market. To implement a mixed concentration measure, we calculated the HHI in 1992 for each OKONKh at each geographic level (RegConc $c_{i j}$ for the regional HHI of firm $i$ in 5-digit industry $j$ and $N a t C o n c_{i j}$ for the national HHI) and combined them into a single index as follows:

$$
\text { Conc }_{i j}=\operatorname{RegProp}_{j} * \operatorname{Reg}_{\text {Conc }} i j+\left(1-\operatorname{RegProp}_{j}\right) * \text { NatConc }_{i j},
$$

where $\operatorname{RegProp}_{j}$ refers to the proportion of regions with at least one firm in industry $j$. For import penetration we use the average of the annual rates in 1992-96, the only years available. We employ dummies for exporters in 1993, 1994, 1996, or 1997, the only years for which we have export information. Finally, we calculate a Herfindahl-Hirschman Index for 1992 industrial employment concentration in each municipality $(5,061$ communities in our database in 1992).

The descriptive results show only negligible differences across quintiles of firms according to their level of product market concentration. For import penetration we find little difference across quintiles in the pre-reform period, while job destruction in the post-reform period is slightly higher for firms facing greater import competition. Our results for exports show lower job creation, destruction, reallocation, net employment decline, and excess reallocation for exporters than non-exporters. In the pre-reform period, less concentrated labor

\footnotetext{
7 There are 89 regions, but our database contains only 77 because 10 smaller districts (okrugi) are grouped together with surrounding regions, and the database does not cover Chechnya and Ingushetia.
} 
markets show lower creation and higher destruction, while post-reform, creation roughly evens out (at a higher level), while the differentials in average destruction rates remain about the same (again, at a higher level).

The employment growth regression results show no significant differences across firms by exposure to competition, with the exception that exporting is associated with more job destruction post-reform (contrary to the descriptive results). The excess job reallocation regression results suggest that exposure to competition is highly negatively associated with the propensity to create jobs, as the coefficients on product and labor market concentration significantly increase in the post-reform period, while the coefficient on import penetration becomes even more negative.

Firms with greater fixed costs of labor turnover, for instance due to higher hiring costs or more firm-specific human capital, should have a stronger incentive to hoard labor and may exhibit lower rates of job creation and destruction. This proposition has been the motivation for studies of job flows to examine their relationship with several firm characteristics that may be associated with turnover costs, namely capital and electricity intensity, average wages (in the post-reform period), and average labor productivity. ${ }^{9}$ A second motivation for examining capital and electricity intensity in the Russian context is that, although they are highly correlated with one another (64 percent), they may have very different effects on job flows. Investment levels in Russia have been extremely low during the transition due to the poor investment climate. Thus, capital-intensive firms may have been forced to downsize more than others due to a greater need for investment to continue operating. On the other hand, since the Russian government forbade electric utilities from cutting off non-paying firms during most of

\footnotetext{
${ }^{8}$ In an excess job reallocation regression including average wage, product market and labor market concentration in the first stage rather than size and exports, we find that exporting is associated with more job creation, however, especially post-reform.

${ }^{9}$ Oi (1962) uses the average wage of an occupational group as a proxy for its fixed turnover cost. Note that we are able to measure electricity intensity, while Davis, Haltiwanger and Schuh (1996) study energy intensity.
} 
the transition, electricity has been highly subsidized, particularly benefiting electricityintensive firms. 10 These subsidies may slow job destruction.

The descriptive results show that pre-reform creation and destruction rates are higher at low intensity for both capital and electricity intensity, as is true post-reform for destruction. Post-reform creation rates are similarly ordered for capital intensity, but even out for electricity intensity. Indeed, the highest average creation rate and lowest net employment fall among all electricity intensity classes are observed for the greatest intensity group. Prior to reform, firms that later pay higher wages have lower job destruction rates, while job creation rates are similar across categories. The inverse relationship between average wage and job destruction becomes much stronger in the post-reform period, and job creation becomes positively related to wage. Both job creation and job destruction rates have an inverse relationship with labor productivity in the pre-reform period. The inverse relationship with job destruction becomes much stronger post-reform. The relationship reverses for job creation in the post-reform period, however. Post-reform net employment change by more productive firms is also much less negative than that by less productive ones $(-2.5$ percent in the top quintile vs. -17.5 percent in the bottom quintile).

Turning to the regression results, capital intensity is negatively associated with employment growth in the pre-reform period, and even more so post-reform. Electricity intensity, wages, and labor productivity are significantly positively associated with employment growth in the post-reform period. So the employment growth regression results for three of the four measures are consistent with the story that firms with greater human capital destroy jobs at a slower rate. The capital and electricity intensity results are consistent with the idea that capital-intensive firms have been forced to downsize more due to a lack of

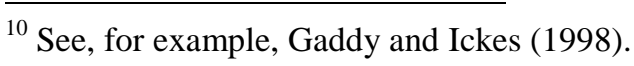


investment, while electricity-intensive firms have been able to retain more of their workforce due to implicit subsidies.

Capital and electricity intensity are negatively associated with job creation, especially during the post-reform period. Firms that later pay higher wages tend to create fewer jobs prior to reform, and this relationship remains the same post-reform, counter to the descriptive results. Except for the positive association between capital intensity and job destruction, all these results are consistent with what DHS find for the U.S. Finally, labor productivity is positively associated with job creation, especially in the post-reform period. The fact that less productive firms are destroying jobs and more productive firms are creating jobs at a much faster rate has positive implications for aggregate productivity, a subject we will investigate further in the next section.

\section{JOB REALLOCATION AND PRODUCTIVITY GROWTH}

This section addresses the impact of job flows on productivity. We use two methods to decompose aggregate productivity change, using extensions of methods used by Foster, Haltiwanger and Krizan (1998) and others. The extension involves an intermediate decomposition of sectoral productivity into its components. In what we call method 1 , by analogy with Foster et al., aggregate productivity change, $\Delta P_{t}$, can be decomposed as follows:

$$
\begin{aligned}
& \Delta P_{t}=\sum_{i} S_{i t-1} \sum_{e} \Delta P_{e i t} S_{e i t-1}+\sum_{i} S_{i t-1} \sum_{e} \Delta S_{e i t}\left(P_{e i t-1}-P_{i t-1}\right)+\sum_{i} S_{i t-1} \sum_{e} \Delta P_{e i t} \Delta S_{e i t}+ \\
& \sum_{i} \Delta S_{i t}\left(P_{i t-1}-P_{t-1}\right)+\sum_{i} \Delta S_{i t} \sum_{e} \Delta P_{e i t} S_{e i t-1}+\sum_{i} \Delta S_{i t} \sum_{e} \Delta S_{e i t}\left(P_{e i t-1}-P_{i t-1}\right)+\sum_{i} \Delta S_{i t} \sum_{e} \Delta P_{e i t} \Delta S_{e i t}
\end{aligned}
$$

where $S$ is the weight (share) of a firm or industry, $t$ indexes years, $i$ indexes industries, and $e$ indexes enterprises within industries, so that $P_{i t}$ is average productivity of sector $i$ in year $t, P_{\text {eit }}$ is the productivity of enterprise $e$ in sector $i$ in year $t$. Thus, the first term refers to the weighted average of firm-level productivity gains (holding composition constant), what we call in Table 11 the "within-firm restructuring" leading to increased productivity. The second term 
measures intra-sectoral compositional changes, weighted by the previous year deviation of enterprise productivity from the industry mean. The third term measures intra-sectoral covariance of productivity and compositional changes. The fourth measures inter-sectoral changes, reflecting compositional changes in industries weighted by previous year deviation of industry productivity from the aggregate mean. The fifth term captures the covariance between inter-sectoral reallocation and intra-sectoral, firm level productivity growth. The sixth measures the covariance of inter-sectoral and intra-sectoral reallocation, while the final, seventh term reflects the joint covariance of inter-sectoral changes, firm-level restructuring, and intra-sectoral composition.

In what we call method 2, again by analogy with Foster et al. (1998), aggregate productivity change, $\Delta P_{t}$, can be decomposed as follows:

$$
\Delta P_{t}=\sum_{i} \bar{S}_{i} \sum_{e} \Delta P_{e i t} \bar{S}_{e i}+\sum_{i} \bar{S}_{i} \sum_{e} \Delta S_{e i t}\left(\bar{P}_{e i}-\bar{P}_{i}\right)+\sum_{i} \Delta S_{i t}\left(\bar{P}_{i}-\bar{P}\right)
$$

The bars over the variables refer to averages of year $t-1$ and $t$. The first term is the "within firm" effect, the second term measures intra-sectoral compositional change, and the third term measures inter-sectoral compositional change.

Following Olley and Pakes (1996), we also conduct a cross-sectional decomposition of labor productivity (denoted method 3):

$$
P_{i t}=\bar{P}_{i}+\sum_{e}\left(S_{e t}-\bar{S}_{i}\right)\left(P_{e t}-\bar{P}_{i}\right)
$$

We then take the weighted average by employment of each industry's decomposition. The first term is the unweighted average of productivity, and the second term shows whether activity is disproportionately located in high productivity (if the term is positive) or low productivity (if the term is negative) firms. When examining the time series pattern, we can see whether the allocation of activity has become more or less productivity enhancing over time. 
As explained by Foster et al. (1998), the main advantage of method 1 relative to method 2 is that within and between effects are distinguished from cross/covariance effects, which are to some extent confounded in method 2. Method 2, however, is less subject to measurement error, a potentially important consideration when using data from Russia. Method 3 has two main advantages: differences in productivity cross-sectionally are more persistent and less affected by measurement error and transitory shocks, and we are able to include entering and exiting firms in addition to continuing firms.

The results from carrying out these decompositions where productivity is measured as average labor productivity (the output-employment ratio) and the firms and industries are weighted by employment shares are shown in Table 11..$^{12}$ Methods 1 and 2 yield very similar results. While within-firm productivity has dropped drastically, both intra-sectoral and intersectoral compositional shifts have gone some way to ameliorating the productivity drop. These two forces offset 19 percent of the total productivity drop that would have occurred otherwise between 1993 and 1999, resulting in an annual average decline of about 10 percent rather than 14 percent. Moreover, these figures represent a large increase in the productivity contributions of job reallocation relative to the pre-reform period, where they had essentially zero contribution to productivity growth.

Another interesting feature of these results is how they vary with the business cycle. The within-firm effect is highly cyclical during the transition period (e.g., note that it is positive in 1996-7 and 1998-99, coinciding with the two years of growth (1997 and 1999)), consistent with Foster et al.'s (1998) results for the U.S. in 1977-1987, while the intra-sectoral and inter-sectoral effects are non-cyclical, unlike in the U.S. (intra-sectoral effects are countercyclical there in 1977-1987). The inter-sectoral effect became significantly positive a year earlier than the intra-sectoral effect (1991-92 vs. 1992-93), and was consistently larger through

\footnotetext{
${ }^{11}$ Unlike methods 1 and 2, method 3 is not affected by the accuracy with which entry and exit are measured.

${ }^{12}$ We have also conducted these decompositions weighting by output, and the qualitative results are similar.
} 
1995-96. The intra-sectoral effect continues to be significantly positive in 1998-99, while the inter-sectoral moved toward zero in 1996-97. This suggests that the early transition was characterized by beneficial resource reallocation across sectors, but that later in the transition intra-sectoral resource reallocation has become a more important source of productivity growth.

Method 3 shows that employment within industries was distributed quite evenly across firms of different productivity levels pre-reform, but more productive firms gained an increasingly large share as the transition progressed, further evidence that reallocation of activity has enhanced productivity only post-reform.

We next examine whether these relationships (using method 2) are statistically significant, using the set of OLS and random effects regressions shown in Table 12. The decline in the within effect is highly statistically significant, as shown in the first two regressions. In the next two regressions we break the intra-sectoral reallocation term into its two components, making the firm employment share of its industry growth the dependent variable and the productivity difference between the firm and the average for the industry (PD) the independent variable. We find that the coefficient on the productivity difference is tiny pre-reform, and actually negative in the OLS specification. The coefficient turns strongly positive and highly significant post-reform. The last two regressions analogously break the inter-sectoral effect into its two components, industry employment share growth on the lefthand-side, and the productivity difference between the industry and all manufacturing on the right-hand-side. The coefficient is near zero and insignificant pre-reform, turning positive and weakly significant (only at the ten percent level) post-reform. Though not reported here, we have also tested the relationships for method 1, and find similar results for the within effect, intra-sectoral reallocation, and inter-sectoral reallocation. We also find the intra-sectoral 
covariance to be positive and significant post-reform, while the inter-sectoral covariance terms are not significant.

A final exercise is to estimate the determinants of the relationship between intrasectoral productivity differences and intra-sectoral firm employment share growth using OLS and fixed effects regressions. Good corporate governance and competition should force less productive firms to contract relative to others in the industry. Thus, we are particularly interested in whether privatization and competition have strengthened the productivityenhancing effect of job reallocation or not. The results in Table 13 show that even when controlling for firm characteristics, reform is estimated to have increased the relationship between PD and the intra-sectoral firm employment share. The relationship between PD and intra-sectoral firm employment share is less positive pre-reform for firms later to be privatized, but it becomes much more positive when ownership changes post-reform. Domestic product market concentration has an insignificant effect on the PD-intra-sectoral firm employment share relationship pre-reform, but it turns negative post-reform (and highly significant when including firm fixed effects). ${ }^{1.3}$ Exporters and firms in industries later facing greater import penetration already had a positive PD-intra-sectoral firm employment share relationship prior to reform, and reform and the actual introduction of import competition did not affect this (suggesting non-random import penetration). Labor market concentration has an insignificant effect on the PD-intra-sectoral firm employment share relationship. When put together with the employment growth and excess job reallocation results above, it appears that privatization and domestic market liberalization (allowing domestic firms to compete with one another) have not led to greater job destruction overall, but rather have helped to focus the destruction in the firms that need it most.

\footnotetext{
${ }^{13}$ A Breusch-Pagan Lagrange multiplier test rejected the hypothesis of the non-existence of firm-specific effects not captured by our controls ( $\mathrm{Chi}^{2}$ statistic of 4.17), and a Hausman test rejected the hypothesis of no systematic difference between the coefficients estimated with fixed and random effects specifications (Chi ${ }^{2}$ of 176). Thus, we prefer the fixed effects specification, though we also display OLS.
} 


\section{CONCLUSION}

Our intent in this paper has not been to offer a complete account of job flows in Russia. Such a task would require much better data on the small firm and non-industrial sectors than we have been able to muster. Rather we have tried to exploit the strengths of our data set: its long time series, covering both the pre- and post-reform periods, and its nearly comprehensive coverage of the old industrial sector. The main questions we have addressed concern the patterns of job flows in this sector, whether there has been substantial change in these patterns since radical economic reforms began in 1992 - in particular in the direction of behavior akin to a market economy, whether job reallocation has become more productivity-enhancing in the post-reform period, and, if so, what factors are associated with that change.

We find that job destruction is by far the dominant flow in the post-reform period, an unsurprising result given our focus on the old industrial sector. But we also note substantial changes in the patterns of flows since 1992: an overall increase in flows relative to the prereform period, and a large increase in the heterogeneity of flows and of firm-level growth. We also find that the impact of job flows on productivity, while negligible before 1992, turned strongly positive thereafter; this result holds equally well for job reallocation within industries and for between-industry flows. Our regression analysis implies that privatization and the unleashing of domestic product market competition have strengthened the within-industry productivity effects. The results provide evidence that, even as the Russian industrial sector goes through a difficult period of downsizing, the overall direction of job reallocation has changed to make destruction more creative. 


\section{DATA APPENDIX}

The firm panel data in this study are constructed from four sets of Goskomstat (State Committee for Statistics) industrial registries. The 1985-1991 data come from the ALBA database of industrial registries. The 1992-1999 data come primarily from 1993-1999 industrial registries obtained directly from Goskomstat. 1992 values are taken mostly from previous year values in the 1993 registry, but they are supplemented with data from the ALBA 1992 registry. We have added foreign-owned industrial firms and joint ventures from the 1993-1999 Goskomstat joint venture registries. We have also added some additional enterprises and filled in missing values for enterprises already in the database from a panel of Goskomstat industrial registries assembled by Economics, Analysis, and Marketing, Inc. (EKAM) of Moscow.

The 1985-1991 data include all non-military industrial enterprises, and the 1992-1999 data include all industrial enterprises with 100 or more employees and those with fewer than 100 employees that are at least 25 percent owned by other legal entities (including the state). In 1992 the registry covered approximately 90.5 percent of total industrial employment.

There are a few hundred cases where both the consolidated and subsidiary records for an entity are present in the same year. To avoid double counting, we dropped the consolidated entity. When the sum of subsidiary employment was smaller than that of the consolidated report, we added an entity with employment equal to the difference between the consolidated entity's employment and the total of the subsidiaries.

We have excluded enterprises belonging to the ministries of culture, education, the environment, health, monuments, the disabled, the blind, the deaf, and the interior, and all industrial firms outside of manufacturing (the latter are included in Table 7, however). We have excluded firm-year observations where employment and output are identical in 1985 and 1990 (2,388 observations), 1986 and 1989 (1,715 observations), or 1987 and 1988 (973 observations). To eliminate implausible outliers, we excluded observations with large 
employment changes scaled by size as follows: firms with below 50 employees in one year that grow to over 250 in the next, firms with between 50 and 199 employees that grow (calculated according to the Davis-Haltiwanger method ${ }^{14}$ ) over 120 percent or under -170 percent, firm with employment between 200 and 499 growing over 100 percent or under -150 percent, and firms with employment of 500 or more growing over 80 percent or under -130 percent. This cleaning resulted in a decrease in the sample by less than one percent each year. The labor productivity decompositions also exclude observations for firms in pairs of years where annual labor productivity growth, calculated using the Davis-Haltiwanger method, exceeds 100 percent or is under -100 percent.

\section{Variable Definitions}

Capital is the rank order of firms by capital intensity, calculated in the following way. We divide average book value of fixed assets used in the main activity of the enterprise by employment for each year in which both values exist in the database. We rank firms by capital intensity in each year. We then calculate the average of the yearly ranks for each firm. Finally, we do a ranking across firms of each firm's average rank, expressed in a range from 0 to 1 , where 1 is the most capital-intensive.

Conc. is product market concentration in 1992, calculated in the following way. We calculate region share, the proportion of regions (oblasts) with at least one enterprise in the five-digit OKONKh industry in 1992. The concentration measure is the regional Herfindahl-Hirschman Index multiplied by region share plus the national Herfindahl-Hirschman Index multiplied by one minus region share.

Electricity is the firm's rank according to the ratio of $\mathrm{kWh}$ of electricity consumption divided by employment in 1993 (the one year in which electricity consumption exists in the database), expressed in a range from 0 to 1 , where 1 is the most electricity-intensive.

Employment is the average number of industrial production personnel (including both production and non-production employees) in the year. The data are partially adjusted by hours of work, as follows: for full-time listed employees, the number is the average of the daily number listed; for part-time listed employees, the number is the full-time equivalent of the contractual hours; for civil contract workers and full-time listed employees on short-time, it is the full-time equivalent of actual hours. When used as a measure of size in Table 8 and in the regressions, employment is the natural log of the average of the firm's employment in all nonmissing years.

$$
{ }_{14} \frac{2\left(e m p_{t}-e m p_{t-1}\right)}{e m p_{t-1}+e m p_{t}}
$$


Export is a dummy variable equal to one if the enterprise exported in 1993, 1994, 1996, or 1997 (the years for which the registries have firm-level export information).

Federal is a dummy variable equal to one if the enterprise has federal state ownership in 1994 (or in 1993, 1995, 1996, 1997, 1998, or 1999 if the enterprise is not in the 1994 registry).

Foreign is a dummy variable equal to one if the enterprise is foreign owned or a foreigndomestic joint venture in 1994 (or in 1993, 1995, 1996, 1997, 1998, or 1999 if the enterprise is not in the 1994 registry).

Imports is the share of imports in domestic sales in the four-digit industry (imports divided by domestic sales (domestic output - exports + imports). Import and export volumes (in U.S. dollars) come from Russian State Customs Committee data by six-digit HC. Domestic output (in rubles) was calculated using our database. To take into account large fluctuations in the exchange rate, tt was divided into monthly volumes using Goskomstat 4-digit monthly production indices. Then average monthly ruble-U.S. dollar exchange rates were applied to the monthly volumes to get domestic output in U.S. dollars. We used the average of the annual import penetration ratios for 1992-1996, the only years for which these data are available.

LaborConc. is a Herfindahl-Hirschman Index of municipal industrial employment concentration in 1992, calculated using the industrial registry.

Labor Productivity is the natural log of output minus the natural log of employment.

Mixed is a dummy variable equal to one if the enterprise has mixed state and non-state ownership in 1994 (or in 1993, 1995, 1996, 1997, 1998, or 1999 if the enterprise is not in the 1994 registry).

Municipal is a dummy variable equal to one if the enterprise has municipal state ownership in 1994 (or in 1993, 1995, 1996, 1997, 1998, or 1999 if the enterprise is not in the 1994 registry).

Nonstate is a dummy variable equal to one if the enterprise is owned by non-state entities in 1994 (or in 1993, 1995, 1996, 1997, 1998, or 1999 if the enterprise is not in the 1994 registry). Note that we do not classify public organizations as either state or non-state - they are excluded from results where non-state ownership is used.

Output is the value of output produced, net of VAT and excise taxes, in 1985 rubles. To deflate output, we use 11-sector OKONKh producer price indices through 1993 and 4 or 5digit (as available) OKONKh industry producer price indices for 1994-99, all from Goskomstat. The 1985-90 annual producer price indices for non-ferrous metallurgy were not available to us, so we imputed annual indices based on the overall change in prices in the sector between 1985-90, assuming that the annual proportions of the total price change for the 6-year period were the same as for industry as a whole.

Private is a dummy variable equal to one if the enterprise is 100 percent privately owned in 1994 (or in 1993, 1995, 1996, 1997, 1998, or 1999 if the enterprise is not in the 1994 registry).

Public is a dummy variable equal to one if the enterprise is owned by a public organization in 1994 (or in 1993, 1995, 1996, 1997, 1998, or 1999 if the enterprise is not in the 1994 registry). 
Regional is a dummy variable equal to one if the enterprise had regional state ownership in 1994 (or in 1993, 1995, 1996, 1997, 1998, or 1999 if the enterprise is not in the 1994 registry).

Wage is a ranking of wages, calculated in the following way. We divide the total wage by the average industrial employment for each year in which both values exist in the database (note that the wage bill is not included in 1985-1991). We rank firms by average wage in each year. We then calculate the average of the yearly ranks for each firm. Finally, we do a ranking across firms of each firm's average rank, expressed in a range from 0 to 1 , where 1 is the highest average wage. 


\section{REFERENCES}

Acquisti, Alessandro and Hartmut Lehmann, "Job Creation and Job Destruction in Russia: Some Preliminary Evidence from Enterprise-Level Data," draft.

Biletsky, Sergiy, et al., "Inside the Transforming Firm: A Report on a Survey of Industrial Enterprise in Russia," 2001.

Bilsen, Valentijn, and Jozef Konings, "Job Creation, Job Destruction, and Growth of Newly Established, Privatized, and State-Owned Enterprises in Transition Economies: Survey Evidence from Bulgaria, Hungary and Romania," Journal of Comp. Econ., 26, 3: 429-45, September 1998.

Brown, J. David, and John S. Earle, "Privatization, Competition, and Reform Strategies: Theory and Evidence from Russian Enterprise Panel Data," CEPR Discussion Paper No. 2758, April 2001.

Caballero, Ricardo J., and Mohammad L. Hammour, "Institutions, Restructuring, and Macroeconomic Performance," NBER Working Paper No. 7720, May 2000.

Cochrane, John, and Barry Ickes, "Macroeconomics in Russia," in Edward P. Lazear (editor), Economic Transition in Eastern Europe and Russia, Stanford: Hoover Institution Press, 1995.

Commander, Simon, John McHale, and Ruslan Yemtsov, "Russia," in Simon Commander and Fabrizio Coricelli (editors), Unemployment, Restructuring, and the Labor Market in Eastern Europe and Russia, EDI Development Studies, Washington: The World Bank, 1995.

Davis, Steven J., and John C. Haltiwanger, "Gross Job Creation, Gross Job Destruction and Employment Reallocation," Quarterly Journal of Economics, 107, 3: 819-63, 1992.

Davis, Steven J., and John C. Haltiwanger, "Gross Job Flows," in Orley Ashenfelter and David Card (editors), Handbook of Labor Economics, Vol. 3, 2712-2803, Amsterdam: Elsevier, 1999.

Davis, Steven J., John C. Haltiwanger, and Scott Schuh, Job Creation and Destruction, Cambridge, Mass.: MIT Press, 1996.

Earle, John S., "Industrial Decline and Labor Reallocation in Romania", working paper, 1997.

Earle, John S., and Saul Estrin, "After Voucher Privatization: The Structure of Corporate Ownership in Russian Manufacturing Industry," CEPR Discussion Paper No. 1736, December 1997.

Earle, John S., and Gheorghe Oprescu, "Romania," in Simon Commander and Fabrizio Coricelli (editors), Unemployment, Restructuring, and the Labor Market in Eastern Europe and Russia, EDI Development Studies, Washington: The World Bank, 1995.

Earle, John S., and Klara Z. Sabirianova, "Russian Labor Markets in Transition: Stylized Facts and New Analysis," working paper, 2001. 
Earle, John S., and Almos Telegdy, "Industrial Productivity Growth and Decline: Results of a Decomposition for Romania," working paper, 2000.

Faggio, Giulia, and Jozef Konings, "Gross Job Flows and Firm Growth in the Transition Countries: Evidence Using Firm Level Data on Five Countries," CEPR Discussion Paper No. 2261, 1999.

Fischer, Stanley, and Ratna Sahay, "The Transition Economics After Ten Years," IMF Working Paper, 2000.

Foster, Lucia, John Haltiwanger, and C.J. Krizan, "Aggregate Productivity Growth: Lessons from Microeconomic Evidence," NBER Working Paper No. 6803, November 1998.

Gaddy, Clifford, and Barry W. Ickes, "An Accounting Model of the Virtual Economy in Russia," Post-Soviet Geography and Economics, 40, 2: 79-97, March 1999.

Gimpelson, Vladimir, and Douglas Lippoldt, "Labour Turnover in the Russian Economy." In OECD, Labour Market Dynamics in the Russian Federation, Paris: OECD, 1997.

Goskomstat, Russian Statistical Yearbook: 1999, Moscow: Goskomstat of Russia, 1999.

Goskomstat, The Economy of the Russian Federation: 1992, Moscow: Goskomstat of Russia, 1992.

Haltiwanger, John, and Milan Vodopivec, "Gross Worker and Job Flows in a Transition Economy: An Analysis of Estonia," working paper, November 2000.

Jurajda, Stepan, and Katernine Terrell, "Optimal Speed of Transition: Micro Evidence from the Czech Republic," working paper, December 2000.

Kapeliushnikov, R., "Job Turnover in a Transitional Economy: The Behaviour and Expectations of Russian Industrial Enterprises." In OECD, Labour Market Dynamics in the Russian Federation, Paris: OECD, 1997.

Konings, Jozef, Hartmut Lehmann, and Mark Schaffer, "Job Creation and Job Destruction in a Transition Economy: Ownership, Firm Size and Gross Job Flows in Polish Manufacturing, 1988-91," Labour Economics, 3, 3: 299-317, October 1996.

Layard, Richard and Andrea Richter. "How Much Unemployment is Needed for Restructuring: The Russian Experience.” Economics of Transition, 3, 1: 35-58, March 1995.

Ofer, Gur, "Soviet Economic Growth, 1928-85," Journal of Economic Literature, Vol. 25, No. 4: 1767-1833, December 1987.

Olley, G. Steven, and Ariel Pakes, "The Dynamics of Productivity in the Telecommunications Equipment Industry," Econometrica, 64, 6: 1263-1297, November 1996.

Oi, Walter, "Labor as a Quasi-Fixed Factor," Journal of Political Economy, Vol. 70, 538-55, 1962. 
Sorm, Vit, and Katherine Terrell, "Sectoral Restructuring and Labor Mobility: A Comparative Look at the Czech Republic," Journal of Comp. Econ., 28, 3: 431-55, September 2000.

Yemtsov, Ruslan, "Ingoing and Outgoing Flows in Employment," paper presented at the IIASA Seminar on Restructuring and Recovering of Output in Russia, June 1994. 
Figure 1: Production, Employment, and Productivity in Russian Industry, 1985-1999

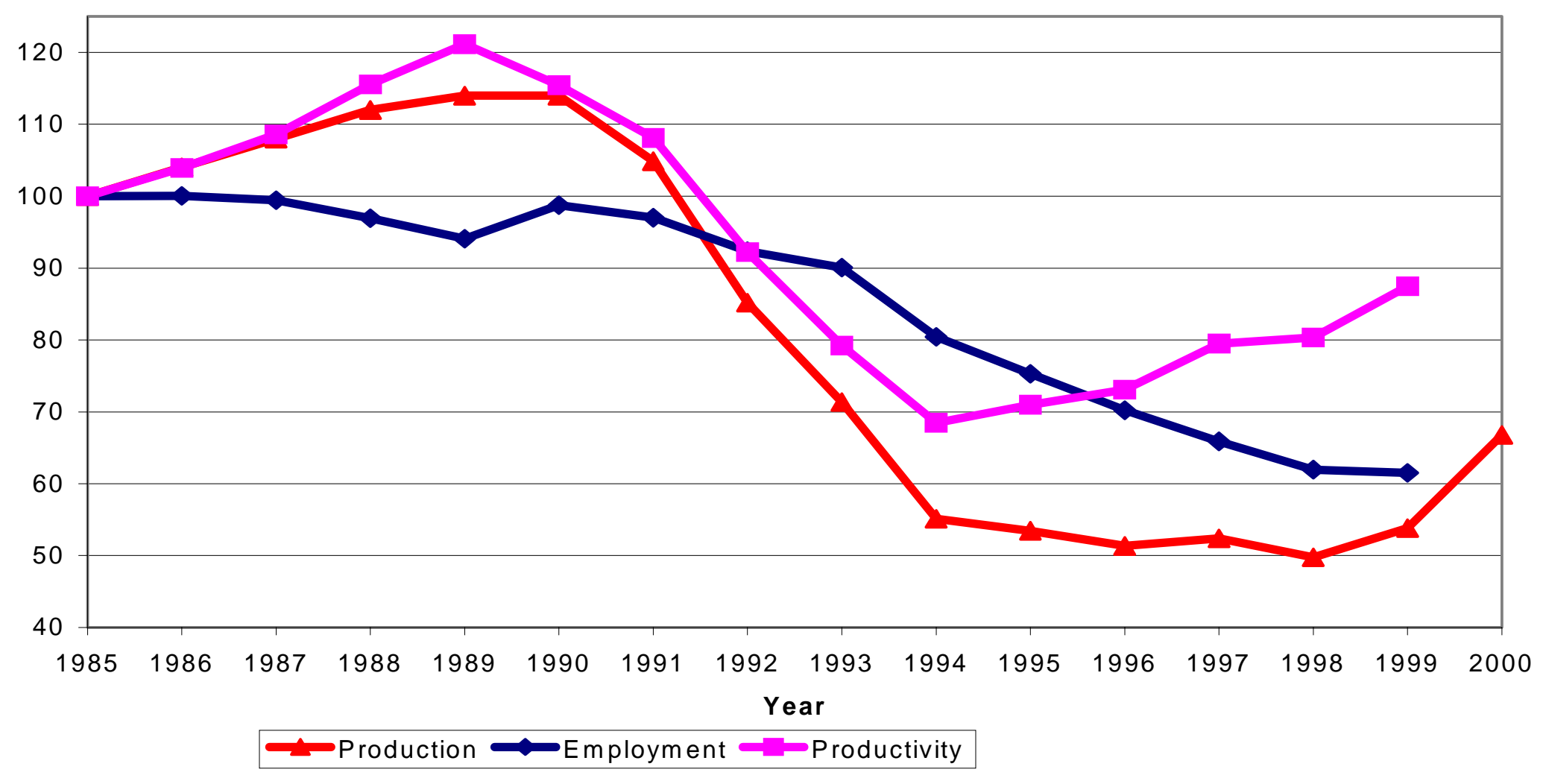

Source: Goskomstat. 
Production in ten industrial sectors: 1985-1999

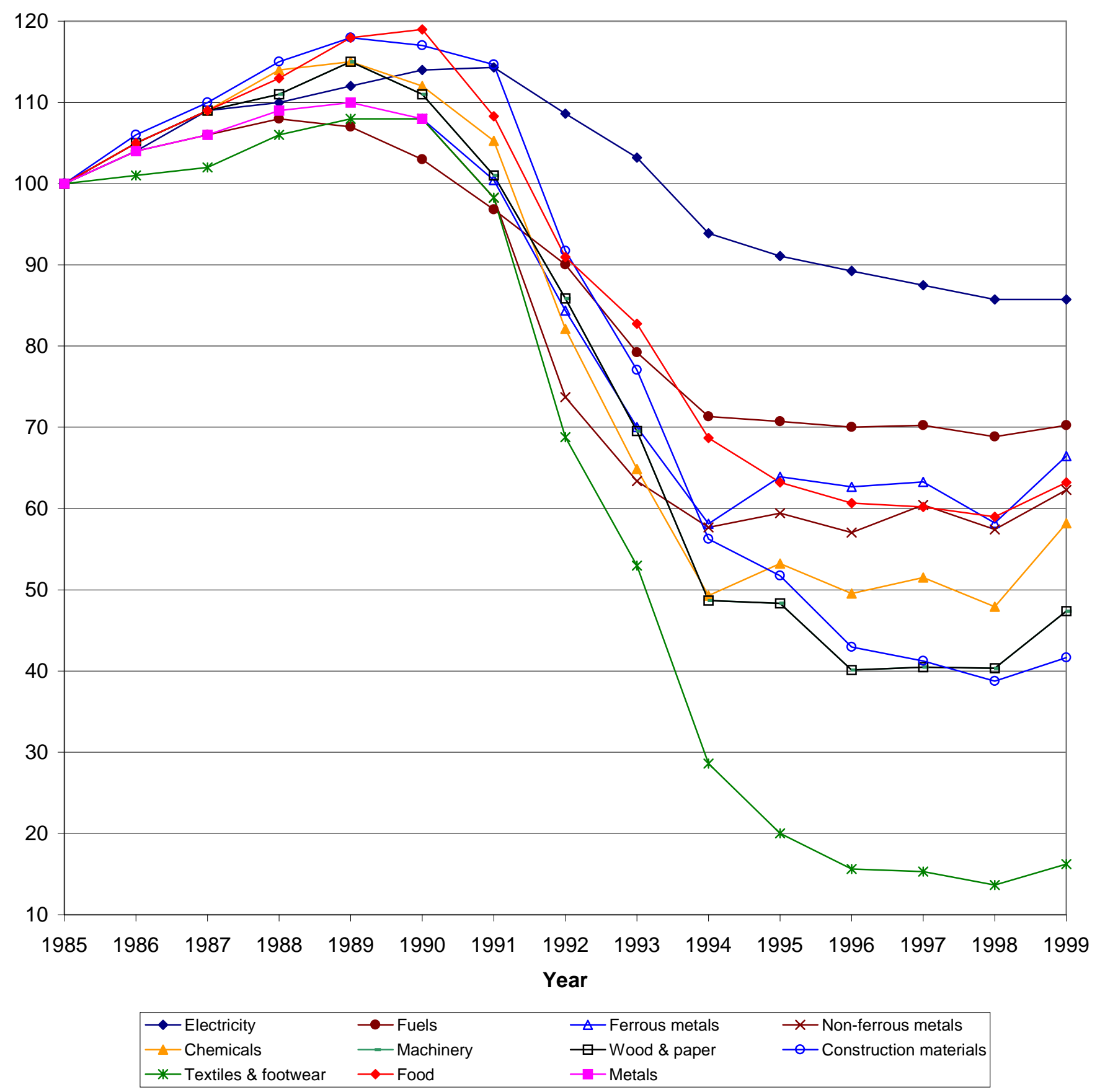

Source: Goskomstat. 


\section{Figure 3: Employment in Ten Industrial Sectors, 1985-1999}

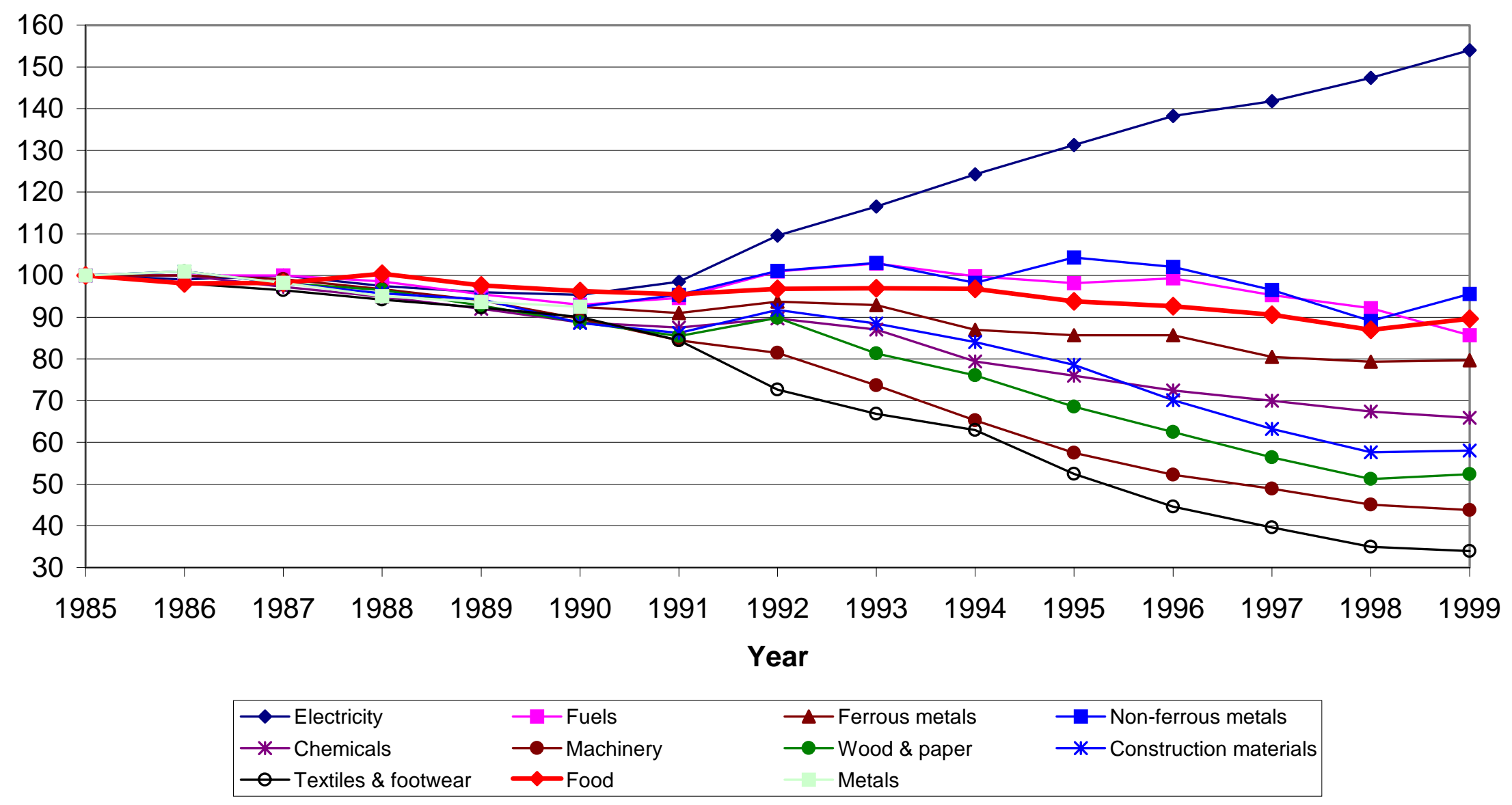

Source: Goskomstat. 


\section{Labor productivity in ten industrial sectors: 1985-1999}

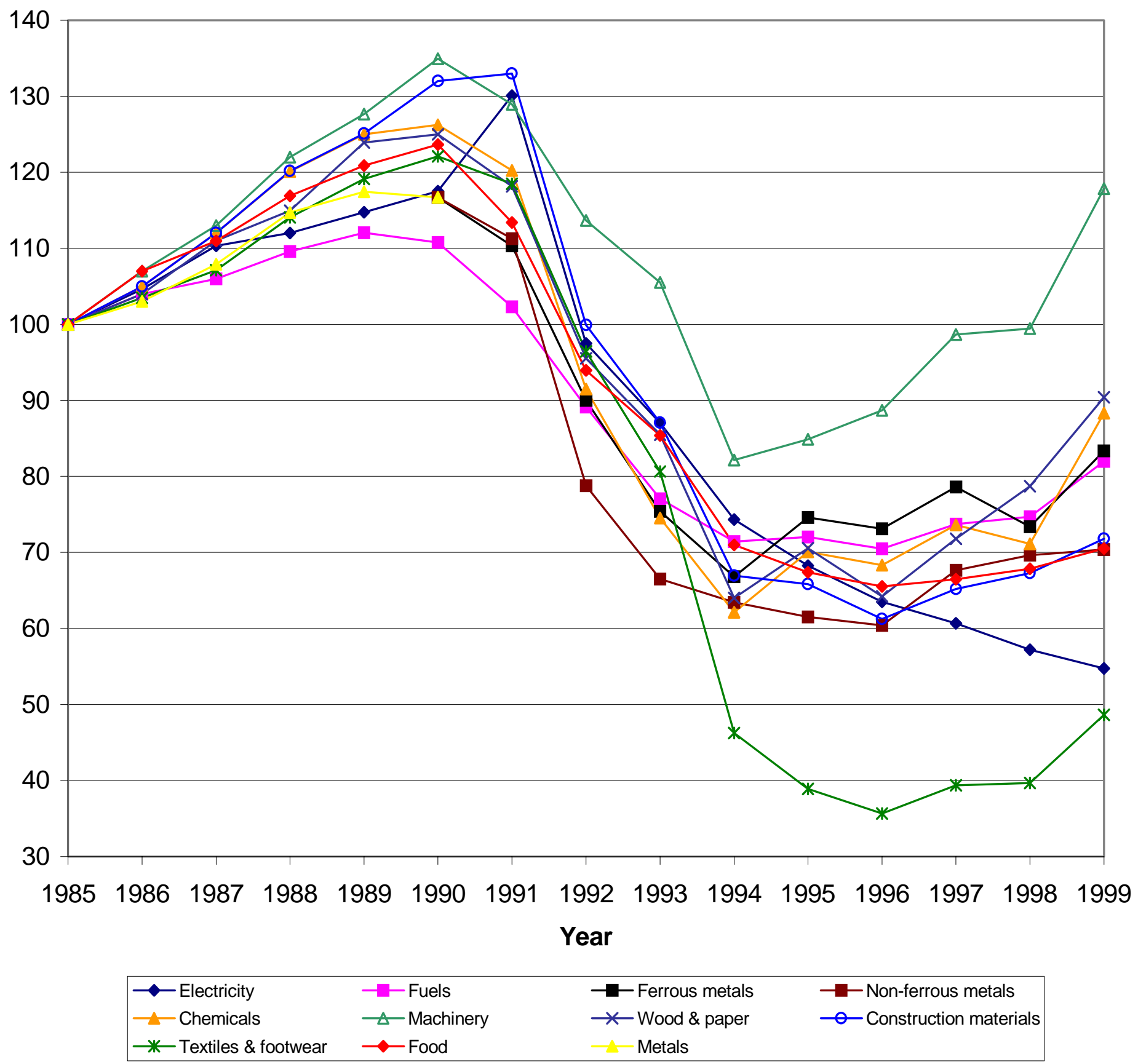

Source: Goskomstat. 
Table 1

Employee Turnover Rates in Russian Industry

(Large and Medium-Size Firms, Percent of Average Employment)

\begin{tabular}{lrrrrrrrr}
\hline & 1992 & 1993 & 1994 & 1995 & 1996 & 1997 & 1998 & 1999 \\
\hline Hiring rate & 22.9 & 20.1 & 18.2 & 21.1 & 16.9 & 19.2 & 19.8 & 27.4 \\
Separation rate & 26.9 & 28.8 & 32.0 & 28.4 & 27.0 & 26.8 & 27.7 & 27.0 \\
\hline
\end{tabular}

Source: Goskomstat.

Table 2

Year-by-Year Job Flow Rates

\begin{tabular}{|c|c|c|c|c|c|c|c|c|}
\hline & $\begin{array}{c}\text { Creation } \\
\text { Rate } \\
\text { (All } \\
\text { Firms) }\end{array}$ & $\begin{array}{c}\text { Creation } \\
\text { Rate } \\
\text { (Creating } \\
\text { Firms) }\end{array}$ & $\begin{array}{c}\text { Destruction } \\
\text { Rate } \\
\text { (All Firms) }\end{array}$ & $\begin{array}{c}\text { Destruction } \\
\text { Rate } \\
\text { (Destroying } \\
\text { Firms) }\end{array}$ & $\begin{array}{c}\text { Realloca } \\
\text {-tion } \\
\text { Rate }\end{array}$ & $\begin{array}{c}\text { Net } \\
\text { Change }\end{array}$ & $\begin{array}{l}\text { Excess } \\
\text { Realloca- } \\
\text { tion }\end{array}$ & $\begin{array}{l}\text { Number } \\
\text { of Firms }\end{array}$ \\
\hline $1985-86$ & 1.9 & 5.7 & 2.1 & 3.2 & 3.9 & -0.2 & 3.7 & 15,429 \\
\hline $1986-87$ & 1.5 & 5.2 & 2.8 & 4.0 & 4.2 & -1.3 & 3.0 & 15,633 \\
\hline $1987-88$ & 1.4 & 8.4 & 5.2 & 6.4 & 6.6 & -3.8 & 2.8 & 16,126 \\
\hline $1988-89$ & 1.3 & 7.2 & 4.6 & 5.8 & 5.9 & -3.3 & 2.6 & 15,589 \\
\hline $1989-90$ & 0.8 & 4.4 & 4.8 & 6.1 & 5.7 & -4.0 & 1.6 & 15,281 \\
\hline $1990-91$ & 1.3 & 6.1 & 7.7 & 10.0 & 9.0 & -6.4 & 2.6 & 15,493 \\
\hline $1991-92$ & 2.6 & 7.1 & 7.4 & 11.8 & 10.0 & -4.8 & 5.1 & 15,017 \\
\hline $1992-93$ & 1.6 & 6.7 & 9.4 & 12.5 & 11.0 & -7.8 & 3.2 & 19,100 \\
\hline 1993-94 & 1.2 & 9.0 & 14.5 & 16.9 & 15.7 & -13.3 & 2.4 & 20,434 \\
\hline 1994-95 & 2.2 & 9.0 & 11.6 & 15.5 & 13.8 & -9.3 & 4.5 & 20,297 \\
\hline $1995-96$ & 3.3 & 11.7 & 9.6 & 13.5 & 12.9 & -6.3 & 6.5 & 20,177 \\
\hline 1996-97 & 1.5 & 7.9 & 13.5 & 16.9 & 15.0 & -12.0 & 3.0 & 18,263 \\
\hline $1997-98$ & 2.3 & 8.6 & 9.4 & 12.9 & 11.7 & -7.2 & 4.5 & 16,367 \\
\hline 1998-99 & 4.1 & 8.7 & 7.3 & 14.0 & 11.4 & -3.3 & 8.1 & 16,330 \\
\hline $1985-91$ & 1.4 & 6.2 & 4.5 & 5.9 & 5.9 & -3.2 & 2.7 & \\
\hline \multicolumn{9}{|l|}{ Average } \\
\hline $1991-99$ & 2.4 & 8.6 & 10.3 & 14.3 & 12.7 & -8.0 & 4.7 & \\
\hline Average & & & & & & & & \\
\hline
\end{tabular}

Source: Authors' calculations. The number of firm-year observations is 93,551 in 1985-91 and 145,985 in 1991-99. 
Table 3

Year-by-Year Job Flow Persistence Rates

\begin{tabular}{lcccccc}
\hline & $\begin{array}{c}\text { 1-Year } \\
\text { Creation } \\
\text { Persistence }\end{array}$ & $\begin{array}{c}\text { 2-Year } \\
\text { Creation } \\
\text { Persistence }\end{array}$ & $\begin{array}{c}\text { 1-Year } \\
\text { Destruction } \\
\text { Persistence }\end{array}$ & $\begin{array}{c}\text { 2-Year } \\
\text { Destruction } \\
\text { Persistence }\end{array}$ & $\begin{array}{c}\text { 1-Year } \\
\text { Reallocation } \\
\text { Persistence }\end{array}$ & $\begin{array}{c}\text { 2-Year } \\
\text { Reallocation } \\
\text { Persistence }\end{array}$ \\
\hline $\begin{array}{l}1985-91 \\
\text { Average }\end{array}$ & 69.5 & 48.3 & 92.3 & 85.1 & 86.9 & 76.0 \\
$\begin{array}{l}\text { 1991-98 } \\
\text { Average* }\end{array}$ & 64.8 & 39.9 & 94.8 & 90.1 & 89.2 & 80.6 \\
\hline *The 2-year creation persistence in the second period is the 1991-97 average.
\end{tabular}

*The 2-year creation persistence in the second period is the 1991-97 average.

Table 4

Distribution of Year-by-Year Employment Growth Rates

\begin{tabular}{lrrrrrrrrr}
\hline & $5 \%$ & $10 \%$ & $25 \%$ & $50 \%$ & $75 \%$ & $90 \%$ & $95 \%$ & Mean & $\begin{array}{c}\text { Standard } \\
\text { Deviation }\end{array}$ \\
\hline $1985-86$ & -12.6 & -6.4 & -2.4 & 0.0 & 1.6 & 6.9 & 13.6 & -0.2 & 13.8 \\
$1986-87$ & -10.5 & -6.6 & -3.0 & -0.5 & 1.5 & 6.9 & 15.5 & 0.7 & 15.1 \\
$1987-88$ & -15.8 & -10.5 & -5.6 & -1.9 & 0.8 & 8.1 & 22.8 & -0.3 & 18.0 \\
$1988-89$ & -15.5 & -10.5 & -5.4 & -1.8 & 0.6 & 6.3 & 14.3 & -1.4 & 14.9 \\
$1989-90$ & -15.5 & -10.7 & -5.7 & -1.9 & 0.4 & 4.7 & 9.2 & -2.5 & 11.9 \\
$1990-91$ & -27.3 & -18.5 & -9.6 & -3.1 & 1.3 & 7.4 & 14.5 & -4.4 & 17.3 \\
$1991-92$ & -31.9 & -23.1 & -12.1 & -3.6 & 2.8 & 10.5 & 17.4 & -5.1 & 18.2 \\
$1992-93$ & -35.3 & -26.7 & -15.1 & -5.6 & 1.6 & 9.4 & 17.0 & -6.7 & 19.3 \\
$1993-94$ & -44.9 & -33.7 & -20.5 & -9.4 & -0.3 & 7.1 & 16.0 & -11.0 & 22.9 \\
$1994-95$ & -47.4 & -35.0 & -19.8 & -7.6 & 1.0 & 11.8 & 25.4 & -9.2 & 26.4 \\
$1995-96$ & -47.3 & -33.3 & -17.9 & -6.7 & 0.9 & 12.8 & 26.3 & -8.3 & 27.1 \\
$1996-97$ & -55.1 & -37.2 & -20.4 & -8.5 & 0.0 & 9.0 & 19.2 & -11.6 & 26.8 \\
$1997-98$ & -54.2 & -34.4 & -16.6 & -5.3 & 1.9 & 11.5 & 21.5 & -8.9 & 27.5 \\
$1998-99$ & -52.5 & -29.8 & -11.4 & -1.1 & 5.6 & 16.9 & 28.6 & -4.9 & 29.6 \\
\hline $1985-91$ & -16.2 & -10.5 & -5.3 & -1.5 & 1.0 & 6.7 & 15.0 & -1.4 & 15.2 \\
Average & & & & & & & & & \\
$1991-99$ & -46.1 & -31.7 & -16.7 & -6.0 & 1.7 & 11.1 & 21.4 & -8.2 & 24.7 \\
Average & & & & & & & & & \\
\hline
\end{tabular}


Table 5

Standard Deviation of Job Flow Rates by Region and Industry

\begin{tabular}{|c|c|c|c|c|c|c|}
\hline & & Creation & Destruction & Reallocation & Net Change & $\begin{array}{c}\text { Excess } \\
\text { Reallocation }\end{array}$ \\
\hline \multirow{4}{*}{$\begin{array}{l}\stackrel{\Xi}{0} \\
\stackrel{0}{00} \\
\mathscr{\simeq}\end{array}$} & $1985-91$ & 1.2 & 1.9 & 2.5 & 2.1 & 2.0 \\
\hline & Average & & & & & \\
\hline & 1991-99 & 1.7 & 4.2 & 4.2 & 4.9 & 2.9 \\
\hline & Average & & & & & \\
\hline \multirow{4}{*}{ 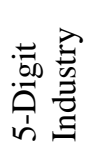 } & $1985-91$ & 3.3 & 2.9 & 4.7 & 5.0 & 2.0 \\
\hline & Average & & & & & \\
\hline & 1991-99 & 2.9 & 7.0 & 6.6 & 8.4 & 3.6 \\
\hline & Average & & & & & \\
\hline
\end{tabular}

Table 6

Share of Excess Job Reallocation Resulting from Employment Shifts Between Sectors

\begin{tabular}{|c|c|c|c|c|c|c|}
\hline & \multicolumn{3}{|c|}{ 1985-91 Average } & \multicolumn{3}{|c|}{ 1991-99 Average } \\
\hline & $\%$ Between & $\begin{array}{c}\text { Average } \\
\text { Number of } \\
\text { Categories }\end{array}$ & $\begin{array}{l}\text { Average } \\
\text { Cell Size }\end{array}$ & $\%$ Between & $\begin{array}{c}\text { Average } \\
\text { Number of } \\
\text { Categories }\end{array}$ & $\begin{array}{l}\text { Average } \\
\text { Cell Size }\end{array}$ \\
\hline $\begin{array}{l}\text { 5-digit } \\
\text { Industry }\end{array}$ & 12.0 & 240 & 61 & 17.7 & 263 & 68 \\
\hline $\begin{array}{l}\text { 2-digit } \\
\text { Industry } \\
\text { 2-digit } \\
\text { Industry by: }\end{array}$ & 1.3 & 9 & 1,621 & 5.2 & 9 & 2,038 \\
\hline $\begin{array}{l}\text { Average } \\
\text { Size }\end{array}$ & 11.5 & 43 & 339 & 6.7 & 45 & 408 \\
\hline $\begin{array}{l}\text { Capital } \\
\text { Intensity }\end{array}$ & 4.7 & 42 & 347 & 8.0 & 44 & 414 \\
\hline $\begin{array}{l}\text { Average } \\
\text { Wage }\end{array}$ & 5.0 & 43 & 338 & 10.2 & 44 & 420 \\
\hline Ownership & 3.1 & 60 & 243 & 7.5 & 61 & 304 \\
\hline Region & 21.9 & 580 & 25 & 23.2 & 620 & 29 \\
\hline $\begin{array}{l}\text { Region and } \\
\text { Size }\end{array}$ & 44.1 & 2,041 & 7.2 & 32.2 & 2,277 & 7.9 \\
\hline
\end{tabular}


Table 7

Employment and Job Flows by Sector, 1994-99

\begin{tabular}{|c|c|c|c|c|c|c|}
\hline & Hires & Separations & Creation & Destruction & $\begin{array}{c}\text { Creation/ } \\
\text { Hires }\end{array}$ & $\begin{array}{l}\text { Destruction/ } \\
\text { Separations }\end{array}$ \\
\hline All Industry & 20.4 & 28.2 & 2.7 & 10.5 & 0.132 & 0.371 \\
\hline Electricity & 17.8 & 16.3 & 5.0 & 2.0 & 0.275 & 0.127 \\
\hline Fuel & 21.9 & 29.5 & 3.7 & 9.3 & 0.171 & 0.324 \\
\hline $\begin{array}{l}\text { Oil } \\
\text { Extraction* }\end{array}$ & 24.8 & 31.5 & 5.9 & 9.7 & 0.227 & 0.356 \\
\hline Oil Refining* & 14.2 & 19.0 & 3.5 & 5.1 & 0.277 & 0.252 \\
\hline Natural Gas* & 21.0 & 19.9 & 11.9 & 3.1 & 0.616 & 0.147 \\
\hline Coal* & 21.5 & 32.5 & 2.0 & 10.6 & 0.094 & 0.323 \\
\hline $\begin{array}{l}\text { Ferrous } \\
\text { Metallurgy }\end{array}$ & 18.7 & 22.0 & 3.2 & 6.5 & 0.190 & 0.303 \\
\hline $\begin{array}{l}\text { Non-Ferrous } \\
\text { Metallurgy }\end{array}$ & 22.9 & 28.7 & 3.8 & 9.3 & 0.191 & 0.333 \\
\hline Chemicals & 17.8 & 23.4 & 2.4 & 7.7 & 0.139 & 0.327 \\
\hline $\begin{array}{l}\text { Machine- } \\
\text { Building }\end{array}$ & 16.6 & 26.8 & 1.6 & 12.3 & 0.095 & 0.455 \\
\hline Forestry & 30.2 & 40.0 & 3.5 & 13.0 & 0.115 & 0.326 \\
\hline $\begin{array}{l}\text { Construction } \\
\text { Materials }\end{array}$ & 33.0 & 39.6 & 3.0 & 8.7 & 0.091 & 0.221 \\
\hline Light & 19.0 & 33.7 & 1.6 & 16.0 & 0.078 & 0.476 \\
\hline $\begin{array}{l}\text { Food } \\
\text { Processing }\end{array}$ & 27.9 & 30.9 & 4.5 & 8.2 & 0.159 & 0.268 \\
\hline
\end{tabular}

*These are subdivisions of the fuel sector.

Table 8

Job Flows by Firm Characteristics

\begin{tabular}{|c|c|c|c|c|c|c|}
\hline Employment & & Creation & Destruction & Reallocation & Net Change & $\begin{array}{c}\text { Excess } \\
\text { Reallocation }\end{array}$ \\
\hline \multirow[t]{4}{*}{$1-99$} & $1985-91$ & 4.4 & 4.1 & 8.5 & 0.3 & 7.4 \\
\hline & Average & & & & & \\
\hline & $1991-99$ & 5.5 & 10.9 & 16.4 & -5.4 & 11.0 \\
\hline & Average & & & & & \\
\hline \multirow[t]{4}{*}{$100-249$} & 1985-91 & 3.0 & 4.3 & 7.3 & -1.4 & 5.6 \\
\hline & Average & & & & & \\
\hline & $1991-99$ & 4.1 & 10.8 & 14.9 & -6.7 & 8.2 \\
\hline & Average & & & & & \\
\hline \multirow[t]{4}{*}{$250-499$} & $1985-91$ & 1.5 & 4.7 & 6.2 & -3.1 & 3.1 \\
\hline & Average & & & & & \\
\hline & 1991-99 & 3.3 & 10.8 & 14.1 & -7.5 & 7.1 \\
\hline & Average & & & & & \\
\hline \multirow[t]{4}{*}{$500-999$} & $1985-91$ & 1.0 & 4.6 & 5.6 & -3.6 & 2.1 \\
\hline & Average & & & & & \\
\hline & 1991-99 & 2.6 & 11.3 & 13.9 & -8.7 & 5.2 \\
\hline & Average & & & & & \\
\hline \multirow[t]{4}{*}{$>=1000$} & $1985-91$ & 0.7 & 3.8 & 4.6 & -3.1 & 1.5 \\
\hline & Average & & & & & \\
\hline & 1991-99 & 1.8 & 10.0 & 11.8 & -8.2 & 3.6 \\
\hline & Average & & & & & \\
\hline
\end{tabular}

The number of firm-year observations is 93,551 in 1985-91 and 145,985 in 1991-99. 


\begin{tabular}{|c|c|c|c|c|c|c|}
\hline Ownership & & Creation & Destruction & Reallocation & Net Change & $\begin{array}{c}\text { Excess } \\
\text { Reallocation }\end{array}$ \\
\hline \multirow[t]{2}{*}{ State* } & $\begin{array}{l}\text { 1985-91 } \\
\text { Average }\end{array}$ & 1.7 & 5.1 & 6.8 & -3.4 & 3.4 \\
\hline & $\begin{array}{l}\text { 1991-99 } \\
\text { Average }\end{array}$ & 1.9 & 11.9 & 13.7 & -10.0 & 3.7 \\
\hline \multirow[t]{2}{*}{ Non-State* } & $\begin{array}{l}1985-91 \\
\text { Average }\end{array}$ & 1.0 & 3.7 & 4.7 & -2.7 & 2.0 \\
\hline & $\begin{array}{l}1991-99 \\
\text { Average }\end{array}$ & 2.4 & 10.0 & 12.4 & -7.6 & 4.8 \\
\hline \multirow[t]{2}{*}{ State** } & $\begin{array}{l}1985-91 \\
\text { Average }\end{array}$ & 1.2 & 4.6 & 5.8 & -3.5 & 2.3 \\
\hline & $\begin{array}{l}\text { 1991-99 } \\
\text { Average }\end{array}$ & 2.1 & 8.9 & 11.0 & -6.8 & 4.2 \\
\hline \multirow[t]{2}{*}{ Non-State $* *$} & $\begin{array}{l}1985-91 \\
\text { Average }\end{array}$ & 0.9 & 3.4 & 4.2 & -2.5 & 1.7 \\
\hline & $\begin{array}{l}\text { 1991-99 } \\
\text { Average }\end{array}$ & 2.2 & 7.9 & 10.0 & -5.7 & 4.4 \\
\hline
\end{tabular}

*These include firms with incomplete employment series. **These include only firms with complete employment series for 1985-1999. The number of firm-year observations is 69,527 in 1985-91 and 139,407 in 1991-99 for the first exercise and 37,404 in 1985-91 and 49,872 in 1991-99 for the second.

\begin{tabular}{|c|c|c|c|c|c|c|}
\hline $\begin{array}{l}\text { Disaggregate } \\
\text { Ownership }\end{array}$ & & Creation & Destruction & Reallocation & Net Change & $\begin{array}{c}\text { Excess } \\
\text { Reallocation }\end{array}$ \\
\hline \multirow[t]{2}{*}{ Federal State } & 1985-91 & 1.1 & 5.0 & 6.1 & -3.9 & 2.3 \\
\hline & $\begin{array}{l}\text { Average } \\
\text { 1991-99 } \\
\text { Average }\end{array}$ & 1.5 & 12.0 & 13.5 & -10.6 & 2.9 \\
\hline \multirow[t]{2}{*}{ Regional State } & $\begin{array}{l}\text { 1985-91 } \\
\text { Average }\end{array}$ & 2.0 & 4.8 & 6.8 & -2.7 & 3.8 \\
\hline & $\begin{array}{l}\text { 1991-99 } \\
\text { Average }\end{array}$ & 3.2 & 11.2 & 14.4 & -8.0 & 6.4 \\
\hline \multirow[t]{2}{*}{$\begin{array}{l}\text { Municipal } \\
\text { State }\end{array}$} & $\begin{array}{l}\text { 1985-91 } \\
\text { Average }\end{array}$ & 3.6 & 6.1 & 9.7 & -2.6 & 6.5 \\
\hline & $\begin{array}{l}\text { 1991-99 } \\
\text { Average }\end{array}$ & 3.8 & 10.8 & 14.6 & -7.0 & 7.6 \\
\hline Public & $1985-91$ & 2.4 & 5.9 & 8.3 & -3.4 & 2.8 \\
\hline Organizations & $\begin{array}{l}\text { Average } \\
\text { 1991-99 } \\
\text { Average }\end{array}$ & 3.4 & 13.6 & 17.0 & -10.2 & 6.7 \\
\hline \multirow[t]{2}{*}{ Mixed } & $\begin{array}{l}\text { 1985-91 } \\
\text { Average }\end{array}$ & 1.0 & 3.5 & 4.5 & -2.5 & 1.9 \\
\hline & $\begin{array}{l}\text { 1991-99 } \\
\text { Average }\end{array}$ & 2.2 & 9.8 & 12.0 & -7.6 & 4.4 \\
\hline \multirow[t]{2}{*}{ Private } & $\begin{array}{l}\text { 1985-91 } \\
\text { Average }\end{array}$ & 1.0 & 3.9 & 5.0 & -3.0 & 2.0 \\
\hline & $\begin{array}{l}\text { 1991-99 } \\
\text { Average }\end{array}$ & 2.5 & 10.1 & 12.6 & -7.6 & 5.0 \\
\hline \multirow[t]{2}{*}{$\begin{array}{l}\text { Foreign Joint } \\
\text { Venture }\end{array}$} & $\begin{array}{l}\text { 1985-91 } \\
\text { Average }\end{array}$ & 0.5 & 4.0 & 4.4 & -3.4 & 1.1 \\
\hline & $\begin{array}{l}\text { 1991-99 } \\
\text { Average }\end{array}$ & 6.0 & 12.0 & 18.0 & -6.0 & 11.9 \\
\hline
\end{tabular}

The number of firm-year observations is 69,527 in 1985-91 and 139,407 in 1991-99. 


\begin{tabular}{|c|c|c|c|c|c|c|}
\hline \multicolumn{2}{|c|}{$\begin{array}{l}\text { Product Market } \\
\text { Concentration }\end{array}$} & Creation & Destruction & Reallocation & $\begin{array}{c}\text { Net } \\
\text { Change }\end{array}$ & $\begin{array}{c}\text { Excess } \\
\text { Reallocation }\end{array}$ \\
\hline \multirow[t]{2}{*}{$80-100^{\text {th }} \%$} & $\begin{array}{l}\text { 1985-91 } \\
\text { Average }\end{array}$ & 1.3 & 3.2 & 4.5 & -2.0 & 2.6 \\
\hline & $\begin{array}{l}\text { 1991-99 } \\
\text { Average }\end{array}$ & 2.3 & 10.2 & 12.4 & -7.9 & 4.5 \\
\hline \multirow[t]{2}{*}{$60-80^{\text {th }} \%$} & $\begin{array}{l}\text { 1985-91 } \\
\text { Average }\end{array}$ & 0.9 & 3.8 & 4.8 & -2.9 & 1.9 \\
\hline & $\begin{array}{l}1991-99 \\
\text { Average }\end{array}$ & 2.1 & 9.4 & 11.5 & -7.3 & 4.2 \\
\hline \multirow[t]{2}{*}{$40-60^{\text {th }} \%$} & $\begin{array}{l}\text { 1985-91 } \\
\text { Average }\end{array}$ & 0.8 & 3.6 & 4.5 & -2.8 & 1.7 \\
\hline & $\begin{array}{l}1991-99 \\
\text { Average }\end{array}$ & 2.1 & 10.1 & 12.2 & -7.9 & 4.2 \\
\hline \multirow[t]{2}{*}{$20-40^{\text {th }} \%$} & $\begin{array}{l}\text { 1985-91 } \\
\text { Average }\end{array}$ & 1.2 & 4.6 & 5.8 & -3.4 & 2.4 \\
\hline & $\begin{array}{l}\text { 1991-99 } \\
\text { Average }\end{array}$ & 2.1 & 12.1 & 14.2 & -10.0 & 4.2 \\
\hline \multirow[t]{2}{*}{$0-20^{\text {th }} \%$} & $\begin{array}{l}1985-91 \\
\text { Average }\end{array}$ & 1.2 & 4.3 & 5.6 & -3.2 & 2.4 \\
\hline & $\begin{array}{l}1991-99 \\
\text { Average }\end{array}$ & 2.8 & 10.3 & 13.1 & -7.5 & 5.6 \\
\hline
\end{tabular}

The number of firm-year observations is 70,960 in 1985-91 and 132,653 in 1991-99.

\begin{tabular}{|c|c|c|c|c|c|c|}
\hline \multicolumn{2}{|c|}{ Import Penetration } & \multirow{2}{*}{$\begin{array}{c}\text { Creation } \\
1.2\end{array}$} & \multirow{2}{*}{$\begin{array}{c}\text { Destruction } \\
4.4\end{array}$} & \multirow{2}{*}{$\begin{array}{c}\text { Reallocation } \\
5.6\end{array}$} & \multirow{2}{*}{\begin{tabular}{|c|}
$\begin{array}{c}\text { Net } \\
\text { Change }\end{array}$ \\
-3.2
\end{tabular}} & \multirow{2}{*}{$\begin{array}{c}\begin{array}{c}\text { Excess } \\
\text { Reallocation }\end{array} \\
2.4\end{array}$} \\
\hline $80-100^{\text {th }} \%$ & $1985-91$ & & & & & \\
\hline & Average & & & & & \\
\hline & $1991-99$ & 2.3 & 12.1 & 14.4 & -9.8 & 4.6 \\
\hline & Average & & & & & \\
\hline \multirow[t]{4}{*}{$60-80^{\text {th }} \%$} & $1985-91$ & 1.2 & 4.4 & 5.7 & -3.2 & 2.4 \\
\hline & Average & & & & & \\
\hline & $1991-99$ & 2.2 & 10.4 & 12.6 & -8.1 & 4.5 \\
\hline & Average & & & & & \\
\hline \multirow[t]{4}{*}{$40-60^{\text {th }} \%$} & $1985-91$ & 1.5 & 5.1 & 6.7 & -3.6 & 3.1 \\
\hline & Average & & & & & \\
\hline & $1991-99$ & 2.2 & 11.4 & 13.6 & -9.2 & 4.4 \\
\hline & Average & & & & & \\
\hline \multirow[t]{4}{*}{$20-40^{\text {th }} \%$} & $1985-91$ & 0.9 & 3.0 & 3.9 & -1.6 & 1.8 \\
\hline & Average & & & & & \\
\hline & $1991-99$ & 2.3 & 8.7 & 11.0 & -6.5 & 4.5 \\
\hline & Average & & & & & \\
\hline \multirow[t]{3}{*}{$0-20^{\text {th }} \%$} & $1985-91$ & 1.5 & 4.5 & 6.0 & -3.0 & 3.0 \\
\hline & Average & & & & & \\
\hline & $1991-99$ & 2.7 & 9.4 & 12.0 & -6.7 & 5.4 \\
\hline
\end{tabular}

The number of firm-year observations is 85,455 in 1985-91 and 139,306 in 1991-99. 


\begin{tabular}{|c|c|c|c|c|c|c|}
\hline Exporting & & Creation & Destruction & Reallocation & Net Change & $\begin{array}{c}\text { Excess } \\
\text { Reallocation }\end{array}$ \\
\hline \multirow[t]{2}{*}{ Exporters } & $\begin{array}{l}\text { 1985-91 } \\
\text { Average }\end{array}$ & 0.8 & 3.6 & 4.4 & -2.8 & 1.5 \\
\hline & $\begin{array}{l}\text { 1991-99 } \\
\text { Average }\end{array}$ & 1.8 & 9.6 & 11.4 & -7.8 & 3.6 \\
\hline \multirow[t]{2}{*}{$\begin{array}{l}\text { Non- } \\
\text { Exporters }\end{array}$} & $\begin{array}{l}1985-91 \\
\text { Average }\end{array}$ & 2.0 & 5.6 & 7.6 & -3.5 & 4.0 \\
\hline & $\begin{array}{l}\text { 1991-99 } \\
\text { Average }\end{array}$ & 3.2 & 11.5 & 14.7 & -8.3 & 6.4 \\
\hline \multicolumn{7}{|c|}{ The number of firm-year observations is 93,551 in $1985-91$ and 144,467 in 1991-99. } \\
\hline \multicolumn{2}{|c|}{$\begin{array}{l}\text { Labor Market } \\
\text { Concentration }\end{array}$} & Creation & Destruction & Reallocation & Net Change & $\begin{array}{c}\text { Excess } \\
\text { Reallocation }\end{array}$ \\
\hline \multirow[t]{2}{*}{$80-100^{\text {th }} \%$} & $\begin{array}{l}\text { 1985-91 } \\
\text { Average }\end{array}$ & 1.2 & 3.3 & 4.5 & -2.1 & 2.4 \\
\hline & $\begin{array}{l}\text { 1991-99 } \\
\text { Average }\end{array}$ & 2.4 & 9.0 & 11.4 & -6.6 & 4.9 \\
\hline \multirow[t]{2}{*}{$60-80^{\text {th }} \%$} & $\begin{array}{l}\text { 1985-91 } \\
\text { Average }\end{array}$ & 1.1 & 2.8 & 3.9 & -1.7 & 2.2 \\
\hline & $\begin{array}{l}\text { 1991-99 } \\
\text { Average }\end{array}$ & 2.0 & 8.0 & 9.9 & -6.0 & 3.9 \\
\hline \multirow[t]{2}{*}{$40-60^{\text {th }} \%$} & $\begin{array}{l}\text { 1985-91 } \\
\text { Average }\end{array}$ & 1.1 & 3.2 & 4.3 & -2.2 & 2.2 \\
\hline & $\begin{array}{l}\text { 1991-99 } \\
\text { Average }\end{array}$ & 2.2 & 9.8 & 11.9 & -7.6 & 4.3 \\
\hline \multirow[t]{2}{*}{$20-40^{\text {th }} \%$} & $\begin{array}{l}\text { 1985-91 } \\
\text { Average }\end{array}$ & 0.9 & 4.0 & 4.9 & -3.1 & 1.8 \\
\hline & $\begin{array}{l}\text { 1991-99 } \\
\text { Average }\end{array}$ & 1.7 & 10.6 & 12.3 & -8.9 & 3.4 \\
\hline \multirow[t]{2}{*}{$0-20^{\text {th }} \%$} & $\begin{array}{l}\text { 1985-91 } \\
\text { Average }\end{array}$ & 0.8 & 5.2 & 6.1 & -4.4 & 1.6 \\
\hline & $\begin{array}{l}1991-99 \\
\text { Average }\end{array}$ & 2.3 & 12.5 & 14.7 & -10.2 & 4.6 \\
\hline
\end{tabular}

The number of firm-year observations is 65,791 in 1985-91 and 129,552 in 1991-99. 


\begin{tabular}{|c|c|c|c|c|c|c|}
\hline $\begin{array}{l}\text { Capital } \\
\text { Intensity }\end{array}$ & & Creation & Destruction & Reallocation & Net Change & $\begin{array}{c}\text { Excess } \\
\text { Reallocation }\end{array}$ \\
\hline \multirow[t]{2}{*}{$80-100^{\text {th }} \%$} & 1985-91 & 1.3 & 3.8 & 5.0 & -2.5 & 2.4 \\
\hline & $\begin{array}{l}\text { 1991-99 } \\
\text { Average }\end{array}$ & 2.7 & 8.9 & 11.6 & -6.2 & 5.3 \\
\hline \multirow[t]{2}{*}{$60-80^{\text {th }} \%$} & $\begin{array}{l}\text { 1985-91 } \\
\text { Average }\end{array}$ & 1.0 & 4.7 & 5.8 & -3.6 & 2.3 \\
\hline & $\begin{array}{l}\text { 1991-99 } \\
\text { Average }\end{array}$ & 1.9 & 11.0 & 12.9 & -9.0 & 3.9 \\
\hline \multirow[t]{2}{*}{$40-60^{\text {th }} \%$} & $\begin{array}{l}\text { 1985-91 } \\
\text { Average }\end{array}$ & 1.2 & 3.8 & 4.9 & -2.6 & 2.3 \\
\hline & $\begin{array}{l}\text { 1991-99 } \\
\text { Average }\end{array}$ & 2.0 & 10.1 & 12.0 & -8.1 & 3.9 \\
\hline \multirow[t]{2}{*}{$20-40^{\text {th }} \%$} & $\begin{array}{l}\text { 1985-91 } \\
\text { Average }\end{array}$ & 2.0 & 5.3 & 7.3 & -3.3 & 4.0 \\
\hline & $\begin{array}{l}1991-99 \\
\text { Average }\end{array}$ & 2.6 & 11.8 & 14.3 & -9.2 & 5.2 \\
\hline \multirow[t]{2}{*}{$0-20^{\text {th }} \%$} & $\begin{array}{l}1985-91 \\
\text { Average }\end{array}$ & 2.3 & 7.7 & 10.0 & -5.3 & 4.7 \\
\hline & $\begin{array}{l}\text { 1991-99 } \\
\text { Average }\end{array}$ & 4.1 & 13.9 & 18.1 & -9.9 & 8.2 \\
\hline
\end{tabular}

The number of firm-year observations is 93,421 in 1985-91 and 137,999 in 1991-99.

\begin{tabular}{|c|c|c|c|c|c|c|}
\hline $\begin{array}{l}\text { Electricity } \\
\text { Per } \\
\text { Worker }\end{array}$ & & Creation & Destruction & Reallocation & Net Change & $\begin{array}{c}\text { Excess } \\
\text { Reallocation }\end{array}$ \\
\hline \multirow[t]{2}{*}{$80-100^{\text {th }} \%$} & $\begin{array}{l}\text { 1985-91 } \\
\text { Average }\end{array}$ & 0.8 & 3.4 & 4.2 & -2.6 & 1.6 \\
\hline & $\begin{array}{l}\text { 1991-99 } \\
\text { Average }\end{array}$ & 2.7 & 6.7 & 9.3 & -4.3 & 5.2 \\
\hline \multirow[t]{2}{*}{$60-80^{\text {th }} \%$} & $\begin{array}{l}\text { 1985-91 } \\
\text { Average }\end{array}$ & 0.9 & 4.0 & 4.9 & -3.1 & 1.8 \\
\hline & $\begin{array}{l}\text { 1991-99 } \\
\text { Average }\end{array}$ & 1.6 & 10.7 & 12.4 & -9.1 & 3.3 \\
\hline \multirow[t]{2}{*}{$40-60^{\text {th }} \%$} & $\begin{array}{l}\text { 1985-91 } \\
\text { Average }\end{array}$ & 1.0 & 4.0 & 5.0 & -2.9 & 2.0 \\
\hline & $\begin{array}{l}\text { 1991-99 } \\
\text { Average }\end{array}$ & 1.8 & 11.7 & 13.5 & -9.8 & 3.7 \\
\hline \multirow[t]{2}{*}{$20-40^{\text {th }} \%$} & $\begin{array}{l}\text { 1985-91 } \\
\text { Average }\end{array}$ & 1.2 & 4.5 & 5.7 & -3.2 & 2.5 \\
\hline & $\begin{array}{l}\text { 1991-99 } \\
\text { Average }\end{array}$ & 1.8 & 13.4 & 15.2 & -11.5 & 3.7 \\
\hline \multirow[t]{2}{*}{$0-20^{\text {th }} \%$} & $\begin{array}{l}\text { 1985-91 } \\
\text { Average }\end{array}$ & 1.6 & 5.2 & 6.8 & -3.7 & 3.2 \\
\hline & $\begin{array}{l}1991-99 \\
\text { Average }\end{array}$ & 1.9 & 14.9 & 16.8 & -13.5 & 3.8 \\
\hline
\end{tabular}

The number of firm-year observations is 63,967 in 1985-91 and 101,357 in 1991-99. 


\begin{tabular}{|c|c|c|c|c|c|c|}
\hline \multicolumn{2}{|c|}{ Average Wage } & \multirow{2}{*}{$\begin{array}{c}\text { Creation } \\
1.0\end{array}$} & \multirow{2}{*}{$\begin{array}{c}\text { Destruction } \\
3.3\end{array}$} & \multirow{2}{*}{$\begin{array}{c}\text { Reallocation } \\
4.3\end{array}$} & \multirow{2}{*}{$\begin{array}{c}\text { Net Change } \\
-2.3\end{array}$} & \multirow{2}{*}{$\begin{array}{c}\begin{array}{c}\text { Excess } \\
\text { Reallocation }\end{array} \\
2.0\end{array}$} \\
\hline $80-100^{\text {th }} \%$ & 1985-91 & & & & & \\
\hline & Average & & & & & \\
\hline & 1991-99 & 3.7 & 5.3 & 9.0 & -1.6 & 6.4 \\
\hline & Average & & & & & \\
\hline \multirow{4}{*}{$60-80^{\text {th }} \%$} & 1985-91 & 0.9 & 3.6 & 4.6 & -2.7 & 1.9 \\
\hline & Average & & & & & \\
\hline & 1991-99 & 2.4 & 8.4 & 10.8 & -6.0 & 4.8 \\
\hline & Average & & & & & \\
\hline \multirow[t]{4}{*}{$40-60^{\text {th }} \%$} & $1985-91$ & 1.0 & 4.3 & 5.3 & -3.3 & 2.0 \\
\hline & Average & & & & & \\
\hline & 1991-99 & 1.9 & 11.8 & 13.7 & -9.9 & 3.8 \\
\hline & Average & & & & & \\
\hline \multirow[t]{4}{*}{$20-40^{\text {th }} \%$} & $1985-91$ & 1.1 & 4.6 & 5.7 & -3.5 & 2.2 \\
\hline & Average & & & & & \\
\hline & $1991-99$ & 1.5 & 14.0 & 15.5 & -12.4 & 3.1 \\
\hline & Average & & & & & \\
\hline \multirow[t]{3}{*}{$0-20^{\text {th }} \%$} & 1985-91 & 1.8 & 5.8 & 7.7 & -4.0 & 3.7 \\
\hline & Average & & & & & \\
\hline & 1991-99 & 1.6 & 18.2 & 19.8 & -16.6 & 3.2 \\
\hline \multicolumn{7}{|c|}{ The number of firm-year observations is 82,309 in $1985-91$ and 139,306 in $1991-99$. } \\
\hline \multicolumn{2}{|c|}{$\begin{array}{l}\text { Average Labor } \\
\text { Productivity }\end{array}$} & Creation & Destruction & Reallocation & $\begin{array}{c}\text { Net } \\
\text { Change }\end{array}$ & $\begin{array}{c}\text { Excess } \\
\text { Reallocation }\end{array}$ \\
\hline \multirow[t]{3}{*}{$80-100^{\text {th }} \%$} & $\begin{array}{l}\text { 1985-91 } \\
\text { Average }\end{array}$ & 1.0 & 3.7 & 4.7 & -2.8 & 1.9 \\
\hline & 1991-99 & 3.6 & 6.0 & 9.5 & -2.5 & 6.7 \\
\hline & Average & & & & & \\
\hline \multirow[t]{3}{*}{$60-80^{\text {th }} \%$} & $1985-91$ & 1.1 & 3.9 & 5.0 & -2.8 & 2.2 \\
\hline & $\begin{array}{l}\text { Average } \\
1991-99\end{array}$ & 2.4 & 8.5 & 10.9 & -6.1 & 4.8 \\
\hline & Average & & & & & \\
\hline \multirow[t]{3}{*}{$40-60^{\text {th }} \%$} & 1985-91 & 1.3 & 4.8 & 6.0 & -3.5 & 2.1 \\
\hline & $\begin{array}{l}\text { Average } \\
1991-99\end{array}$ & 1.7 & 11.6 & 13.3 & -9.9 & 3.4 \\
\hline & Average & & & & & \\
\hline \multirow[t]{4}{*}{$20-40^{\text {th }} \%$} & $1985-91$ & 1.5 & 5.3 & 6.8 & -3.8 & 3.0 \\
\hline & Average & & & & & \\
\hline & 1991-99 & 1.6 & 15.1 & 16.7 & -13.5 & 3.2 \\
\hline & Average & & & & & \\
\hline \multirow[t]{3}{*}{$0-20^{\text {th }} \%$} & 1985-91 & 4.0 & 7.7 & 11.7 & -3.7 & 7.5 \\
\hline & Average & & & & & \\
\hline & 1991-99 & 1.8 & 19.3 & 21.1 & -17.5 & 3.5 \\
\hline
\end{tabular}

The number of firm-year observations is 93,382 in 1985-91 and 143,079 in 1991-99. 
Table 9

Job Flow Regressions

\begin{tabular}{lrrrr}
\hline & Employment Growth & \multicolumn{3}{c}{ Excess Reallocation } \\
\hline Nonstate & 0.011 & $(3.19)$ & -0.043 & $(-30.99)$ \\
Product Market Concentration & -0.010 & $(-1.19)$ & -0.007 & $(-2.12)$ \\
Import Penetration & & & -0.069 & $(-15.37)$ \\
Export & -0.001 & $(-0.21)$ & & \\
Labor Market Concentration & 0.006 & $(1.39)$ & 0.045 & $(19.59)$ \\
Average Capital Intensity & -0.030 & $(-3.99)$ & -0.062 & $(-20.93)$ \\
Average Wage & -0.015 & $(-2.25)$ & -0.019 & $(-5.66)$ \\
Average Labor Productivity & 0.003 & $(0.33)$ & 0.013 & $(3.81)$ \\
Average Employment & $-0.021(-16.23)$ & & \\
Nonstate*Reform & 0.007 & $(1.38)$ & -0.076 & $(-26.09)$ \\
Product Market Concentration*Reform & 0.011 & $(1.12)$ & 0.043 & $(7.71)$ \\
Import Penetration*Reform & 0.019 & $(1.67)$ & -0.142 & $(-19.65)$ \\
Export*Reform & -0.011 & $(-3.02)$ & & \\
Labor Market Concentration*Reform & -0.005 & $(-0.85)$ & 0.109 & $(29.58)$ \\
Average Capital Intensity*Reform & $-0.103(-12.46)$ & -0.140 & $(-30.69)$ \\
Average Wage*Reform & $0.170(19.35)$ & -0.004 & $(-0.75)$ \\
Average Labor Productivity*Reform & 0.104 & $(10.67)$ & 0.041 & $(7.47)$ \\
Average Employment*Reform & $0.013(8.70)$ & & \\
Reform & -0.265 & $(-26.02)$ & 0.243 & $(52.40)$ \\
Constant & 0.140 & $(15.94)$ & 0.117 & $(44.37)$ \\
$\mathrm{R}^{2}$ & 0.037 & 0.268 \\
N & 191,035 & 191,035 \\
\hline
\end{tabular}

Note: $\mathrm{T}$ statistics are in parentheses, using standard errors corrected for clustering on firm id. The regressions include fixed industry-territory effects. Import penetration dropped out of the employment growth regression due to collinearity with the industry-territory effects. 
Table 10

Job Flow Regressions with Disaggregated Ownership

\begin{tabular}{|c|c|c|}
\hline & Employment Growth & Excess Reallocation \\
\hline Municipal & (1.17) & $(8.26)$ \\
\hline Oblast & $-0.001 \quad(-0.13)$ & $(7.14)$ \\
\hline Public Organization & $-0.000 \quad(-0.02)$ & $(-0.65)$ \\
\hline Mixed & $(0.94)$ & $-0.037 \quad(-17.65)$ \\
\hline Private & $(2.82)$ & $-0.032 \quad(-16.12)$ \\
\hline Foreign & $(1.77)$ & $(-5.77)$ \\
\hline Product Concentration & $-0.006 \quad(-0.67)$ & $(-1.69)$ \\
\hline Import Penetration & & $-0.065 \quad(-14.80)$ \\
\hline Export & $(0.05)$ & \\
\hline Labor Market Concentration & $(1.41)$ & $(19.34)$ \\
\hline Capital Intensity & $(-3.47)$ & $-0.059 \quad(-20.17)$ \\
\hline Average Wage & $-0.010 \quad(-1.54)$ & $(-5.14)$ \\
\hline Average Labor Productivity & $-0.006 \quad(-0.60)$ & $(3.25)$ \\
\hline Employment & $-0.021(-16.11)$ & \\
\hline Municipal*Reform & $-0.017 \quad(-1.40)$ & $0.115 \quad(19.87)$ \\
\hline Oblast*Reform & $(1.50)$ & $0.097 \quad(18.60)$ \\
\hline Public Organization*Reform & $(1.81)$ & $(4.21)$ \\
\hline Mixed*Reform & $(1.54)$ & $(-6.24)$ \\
\hline Private*Reform & $(1.19)$ & $(-4.27)$ \\
\hline Foreign*Reform & (7.64) & $(4.71)$ \\
\hline Product Concentration*Reform & $(0.39)$ & $(5.79)$ \\
\hline Import Penetration*Reform & (1.19) & $-0.126 \quad(-17.89)$ \\
\hline Export*Reform & $-0.011 \quad(-2.86)$ & \\
\hline Labor Market Concentration*Reform & $-0.004 \quad(-0.60)$ & $(27.50)$ \\
\hline Capital Intensity*Reform & $-0.103(-12.46)$ & $-0.126 \quad(-28.60)$ \\
\hline Average Wage*Reform & 0.165 (19.04) & $(-0.68)$ \\
\hline Average Labor Productivity*Reform & $0.100 \quad(10.44)$ & $(6.30)$ \\
\hline Employment*Reform & $(8.94)$ & \\
\hline Reform & $-0.265(-22.96)$ & $0.189 \quad(33.02)$ \\
\hline Constant & 0.138 (14.96) & $0.106 \quad(36.81)$ \\
\hline $\mathrm{R}^{2}$ & 0.038 & 0.284 \\
\hline $\mathrm{N}$ & 195,132 & 195,132 \\
\hline
\end{tabular}

Note: T-statistics are in parentheses, using standard errors corrected for clustering on firm id.. The regressions include fixed industry-territory effects. Federal state ownership is the omitted ownership category. 
Table 11

Decomposition of Labor Productivity Growth, Method 1

\begin{tabular}{|c|c|c|c|c|c|c|c|c|}
\hline & $\begin{array}{l}\text { Within } \\
\text { Firm }\end{array}$ & $\begin{array}{l}\text { Intra- } \\
\text { Sector }\end{array}$ & $\begin{array}{l}\text { Intra- } \\
\text { Sector } \\
\text { Cov }\end{array}$ & $\begin{array}{l}\text { Inter- } \\
\text { Sector }\end{array}$ & $\begin{array}{c}\text { Inter- } \\
\text { Sector } \\
\text { Within } \\
\text { Cov }\end{array}$ & $\begin{array}{c}\text { Inter- } \\
\text { Sector } \\
\text { Between } \\
\text { Cov }\end{array}$ & $\begin{array}{c}\text { Inter- } \\
\text { Sector } \\
\text { Cov Cov }\end{array}$ & $\begin{array}{c}\text { Total } \\
\text { Growth }\end{array}$ \\
\hline $1985-86$ & 0.0339 & 0.0008 & -0.0014 & -0.0028 & 0.0001 & 0.0000 & -0.0000 & 0.0307 \\
\hline $1986-87$ & 0.0480 & -0.0002 & -0.0035 & -0.0052 & -0.0002 & -0.0000 & -0.0002 & 0.0386 \\
\hline $1987-88$ & 0.0740 & 0.0000 & -0.0017 & 0.0047 & -0.0000 & -0.0000 & 0.0001 & 0.0771 \\
\hline $1988-89$ & 0.0466 & 0.0022 & -0.0034 & -0.0014 & -0.0003 & -0.0000 & -0.0000 & 0.0436 \\
\hline $1989-90$ & 0.0051 & 0.0021 & -0.0026 & 0.0021 & -0.0004 & -0.0000 & 0.0001 & 0.0062 \\
\hline $1990-91$ & -0.1356 & 0.0041 & 0.0000 & 0.0091 & 0.0006 & -0.0002 & -0.0000 & -0.1221 \\
\hline $1991-92$ & -0.3277 & 0.0040 & 0.0077 & 0.0181 & 0.0166 & 0.0001 & -0.0001 & -0.2814 \\
\hline $1992-93$ & -0.2818 & 0.0209 & -0.0016 & 0.0375 & -0.0022 & -0.0002 & -0.0001 & -0.2275 \\
\hline 1993-94 & -0.4739 & 0.0275 & -0.0081 & 0.0356 & -0.0012 & -0.0002 & 0.0007 & -0.4197 \\
\hline $1994-95$ & -0.2102 & 0.0280 & -0.0042 & 0.0285 & 0.0007 & -0.0003 & -0.0000 & -0.1575 \\
\hline $1995-96$ & -0.2056 & 0.0245 & -0.0048 & 0.0442 & -0.0039 & -0.0002 & -0.0001 & -0.1459 \\
\hline 1996-97 & 0.0280 & 0.0289 & -0.0037 & 0.0099 & -0.0019 & -0.0000 & -0.0000 & 0.0611 \\
\hline $1997-98$ & -0.0101 & 0.0214 & -0.0026 & 0.0078 & 0.0000 & -0.0003 & 0.0001 & 0.0163 \\
\hline 1998-99 & 0.0535 & 0.0175 & -0.0033 & -0.0006 & 0.0028 & -0.0004 & 0.0002 & 0.0697 \\
\hline $1985-90$ & 0.1821 & 0.0079 & -0.0148 & -0.0001 & -0.0010 & -0.0001 & -0.0002 & 0.1738 \\
\hline 1993-99 & -0.6799 & 0.0368 & -0.0072 & 0.0971 & -0.0037 & 0.0006 & 0.0000 & -0.5563 \\
\hline $1985-90$ & 0.0415 & 0.0010 & -0.0025 & -0.0005 & -0.0002 & -0.0000 & -0.0000 & 0.0392 \\
\hline $\begin{array}{l}\text { Average } \\
1993-99 \\
\text { Average }\end{array}$ & -0.1364 & 0.0246 & -0.0045 & 0.0209 & -0.0006 & -0.0002 & 0.0002 & -0.0960 \\
\hline
\end{tabular}

The number of firm-year observations is 86,170 in 1985-91 and 135,061 in 1991-99.

Decomposition of Labor Productivity Growth, Method 2

\begin{tabular}{lrrrr}
\hline & Within Firm & $\begin{array}{l}\text { Intra- } \\
\text { Sector }\end{array}$ & $\begin{array}{c}\text { Inter- } \\
\text { Sector }\end{array}$ & Total Growth \\
\hline $1985-86$ & 0.0333 & 0.0001 & -0.0027 & 0.0307 \\
$1986-87$ & 0.0461 & -0.0020 & -0.0054 & 0.0386 \\
$1987-88$ & 0.0732 & -0.0008 & 0.0048 & 0.0771 \\
$1988-89$ & 0.0447 & 0.0005 & -0.0015 & 0.0436 \\
$1989-90$ & 0.0036 & 0.0008 & 0.0019 & 0.0062 \\
$1990-91$ & -0.1353 & 0.0040 & 0.0093 & -0.1221 \\
$1991-92$ & -0.3156 & 0.0079 & 0.0263 & -0.2814 \\
$1992-93$ & -0.2837 & 0.0200 & 0.0363 & -0.2275 \\
$1993-94$ & -0.4784 & 0.0235 & 0.0353 & -0.4197 \\
$1994-95$ & -0.2119 & 0.0258 & 0.0287 & -0.1575 \\
$1995-96$ & -0.2099 & 0.0220 & 0.0421 & -0.1459 \\
$1996-97$ & 0.0251 & 0.0270 & 0.0089 & 0.0611 \\
$1997-98$ & -0.0113 & 0.0199 & 0.0077 & 0.0163 \\
$1998-99$ & 0.0533 & 0.0157 & 0.0007 & 0.0697 \\
\hline $1985-90$ & 0.1741 & 0.0004 & -0.0007 & 0.1738 \\
$1993-99$ & -0.6854 & 0.0335 & 0.0956 & -0.5563 \\
\hline $1985-90$ & 0.0402 & -0.0003 & -0.0006 & 0.0392 \\
Average & & & & \\
$1993-99$ & -0.1389 & 0.0223 & 0.0206 & -0.0960 \\
Average & & & & \\
\hline
\end{tabular}

The number of firm-year observations is 86,170 in $1985-91$ and 135,061 in 1991-99. 
Cross-Sectional Decomposition of Labor Productivity

\begin{tabular}{ccccc}
\hline & $\begin{array}{c}\text { Weighted } \\
\text { Average } \\
\text { Productivity }\end{array}$ & $\begin{array}{c}\text { Unweighted } \\
\text { Average } \\
\text { Productivity }\end{array}$ & Cross & $\begin{array}{c}\text { Cross/Weighted } \\
\text { Average } \\
\text { Productivity }\end{array}$ \\
\hline 1985 & 2.7090 & 2.6917 & 0.0173 & 0.0064 \\
1986 & 2.7750 & 2.7299 & 0.0451 & 0.0163 \\
1987 & 2.7756 & 2.7494 & 0.0262 & 0.0094 \\
1988 & 2.8720 & 2.8448 & 0.0272 & 0.0095 \\
1989 & 2.9362 & 2.9201 & 0.0161 & 0.0055 \\
1990 & 2.9778 & 2.9544 & 0.0234 & 0.0079 \\
1991 & 3.6319 & 3.6720 & -0.0401 & -0.0110 \\
1992 & 5.7489 & 5.5903 & 0.1586 & 0.0276 \\
1993 & 6.1579 & 5.9753 & 0.1827 & 0.0297 \\
1994 & 5.6585 & 5.4588 & 0.1997 & 0.0353 \\
1995 & 5.5044 & 5.2601 & 0.2443 & 0.0444 \\
1996 & 5.3332 & 5.0878 & 0.2454 & 0.0460 \\
1997 & 5.4019 & 5.0842 & 0.3177 & 0.0588 \\
1998 & 5.5444 & 5.1532 & 0.3913 & 0.0706 \\
1999 & 5.6468 & 5.2410 & 0.4059 & 0.0719 \\
\hline
\end{tabular}

The number of firm-year observations is 107,368 in 1985-91 and 156,902 in 1992-99. 
Table 12

Reallocation Productivity Regressions

\begin{tabular}{|c|c|c|c|c|c|c|}
\hline & $\begin{array}{l}\text { Firm Productivity } \\
\text { Growth (OLS) }\end{array}$ & $\begin{array}{c}\text { Firm Productivity } \\
\text { Growth (Random } \\
\text { Effects) }\end{array}$ & $\begin{array}{c}\text { Firm Employment } \\
\text { Share Growth (OLS) }\end{array}$ & $\begin{array}{l}\text { Firm Employment } \\
\text { Share Growth } \\
\text { (Random Effects) }\end{array}$ & $\begin{array}{c}\text { Industry Employment } \\
\text { Share Growth (OLS) }\end{array}$ & $\begin{array}{c}\text { Industry Employment } \\
\text { Share Growth } \\
\text { (Random Effects) }\end{array}$ \\
\hline Constant & $(0.20)$ & $0.023 \quad(12.03)$ & $0.004 \quad(7.59)$ & $0.018 \quad(12.52)$ & $0.007 \quad(-0.34)$ & $0.010 \quad(0.97)$ \\
\hline Reform & $-0.230(-143.57)$ & $-0.261 \quad(-136.61)$ & $0.001 \quad(0.61)$ & $-0.004 \quad(-3.55)$ & $0.014 \quad(1.86)$ & 0.011 \\
\hline PD & & & $-0.007 \quad(-6.70)$ & $0.007 \quad(4.06)$ & $-0.004 \quad(1.86)$ & $-0.005(-0.36)$ \\
\hline PD*Reform & & & $0.062 \quad(34.33)$ & $0.055 \quad(30.53)$ & $0.023 \quad(1.91)$ & $0.022 \quad(1.72)$ \\
\hline $\mathrm{R}^{2}$ & 0.076 & 0.076 & 0.022 & 0.021 & 0.003 & 0.003 \\
\hline $\mathrm{N}$ & 201,843 & 201,843 & 201,821 & 201,821 & 3,466 & 3,466 \\
\hline
\end{tabular}

Note: $\mathrm{T}$ statistics ( $\mathrm{Z}$ statistics for random effects) are reported in parentheses. The standard errors in the OLS specifications are adjusted for clustering on the firm in the firm regressions and on the industry in the industry regression. PD is the difference in productivity between the firm and the average for the industry in the third and fourth columns, and the difference in productivity between the industry and the average for all manufacturing in the fifth and sixth columns. 
Table 13

Between Firm Reallocation Productivity Regressions

\begin{tabular}{|c|c|c|}
\hline & $\begin{array}{l}\text { Percentage Firm Employment } \\
\text { Share Growth (OLS) }\end{array}$ & $\begin{array}{l}\text { Percentage Firm Employment } \\
\text { Share Growth (Fixed Effects) }\end{array}$ \\
\hline PD & $(1.64)$ & $(0.99)$ \\
\hline PD*Nonstate & $(-1.98)$ & $-0.006 \quad(-1.09)$ \\
\hline PD*Conc. & $(-0.19)$ & $(1.96)$ \\
\hline PD*Imports & $(-0.27)$ & $(2.50)$ \\
\hline PD*Export & $(0.74)$ & $(2.25)$ \\
\hline PD*LaborConc. & $(0.66)$ & $(-0.06)$ \\
\hline PD*Capital & $(-2.82)$ & $(-1.68)$ \\
\hline PD*Wage & $(-0.62)$ & $(5.35)$ \\
\hline PD*Emp. & $(0.37)$ & $(-3.06)$ \\
\hline PD*Reform & $(3.40)$ & $(4.70)$ \\
\hline PD*Nonstate*Reform & (4.79) & $(4.17)$ \\
\hline PD*Conc. $*$ Reform & $(-1.30)$ & $(-3.76)$ \\
\hline PD*Imports*Reform & $(1.41)$ & $-0.005 \quad(-0.30)$ \\
\hline PD*Export*Reform & $(0.91)$ & $(-0.83)$ \\
\hline PD*LaborConc.*Reform & $(-0.95)$ & $(-0.07)$ \\
\hline PD*Capital*Reform & $(-1.57)$ & $(-4.83)$ \\
\hline PD*Wage*Reform & $(4.26)$ & $(1.47)$ \\
\hline PD*Emp.*Reform & $(-0.62)$ & $(1.55)$ \\
\hline Nonstate & $(6.16)$ & \\
\hline Conc. & $(1.52)$ & \\
\hline Imports & (1.63) & \\
\hline Export & (1.97) & \\
\hline LaborConc. & $(8.83)$ & \\
\hline Capital & $(2.75)$ & \\
\hline Wage & $(-2.54)$ & \\
\hline Emp. & $(-9.98)$ & \\
\hline Reform & $(4.50)$ & (4.19) \\
\hline Nonstate*Reform & $(-0.74)$ & $(-0.73)$ \\
\hline Conc.*Reform & $(-1.96)$ & $(-2.17)$ \\
\hline Imports*Reform & $(-1.93)$ & $(-2.71)$ \\
\hline Export*Reform & $(-0.12)$ & $(1.62)$ \\
\hline LaborConc.*Reform & $(2.43)$ & $(2.64)$ \\
\hline Capital*Reform & $-0.073 \quad(-15.46)$ & $-0.081 \quad(-15.00)$ \\
\hline Wage*Reform & $0.017 \quad(3.23)$ & $(1.82)$ \\
\hline Emp.*Reform & $(0.16)$ & $(0.81)$ \\
\hline Constant & $0.015 \quad(4.72)$ & $0.001 \quad(0.77)$ \\
\hline $\mathrm{R}^{2}$ & 0.034 & 0.030 \\
\hline $\mathrm{N}$ & 160,724 & 160,724 \\
\hline
\end{tabular}

Note: T statistics are in parentheses. Standard errors are adjusted for firm clustering in the OLS specification. PD is the difference in productivity between the firm and the average for the industry. 


\section{IZA Discussion Papers}
No. Author(s)
270
B. Augurzky
C. M. Schmidt
271
B. Augurzky
C. M. Schmidt
272
C. Belzil
J. Hansen

273

G. Saint-Paul

274

P.J. Pedersen

N. Smith

275

G. S. Epstein

T. Lecker

276

277

B. Amable

D. Gatti

R. Winter-Ebmer

278

T. M. Andersen

279

T. M. Andersen

280

P. Apps

R. Rees

281

G. Saint-Paul

282
J. Albrecht
A. Björklund
S. Vroman

Title

Area

Date

The Evaluation of Community-Based

6

03/01

Interventions: A Monte Carlo Study

The Propensity Score: A Means to An End

6

$03 / 01$

Heterogeneous Returns to Human Capital and

5

03/01

Dynamic Self-Selection

Distribution and Growth in an Economy with

5

03/01

Limited Needs

Unemployment Traps: Do Financial Dis-

3

03/01 incentives Matter?

Multi-Generation Model of Immigrant Earnings:

1

03/01

Theory and Application

The Impact of Product Market Competition on

5

03/01

Employment and Wages

Evaluating an Innovative Redundancy-Retraining

6

03/01

Project: The Austrian Steel Foundation

Welfare Policies, Labour Taxation and Inter-

2

$04 / 01$

national Integration

Product Market Integration, Wage Dispersion

2

04/01 and Unemployment

7

04/01

the Life Cycle

5

04/01

Elites

Is There a Glass Ceiling in Sweden?

5

04/01 

and the Rising Returns to Skill: US and France 1964-2000 
298

P. Telhado Pereira

Returns to Education and Wage Equations
A. Stutzer

R. Lalive

301

J. R. Frick

G. G. Wagner

302

G. S. Epstein

A. Weiss
H. Bonin
G. Abío
E. Berenguer
J. Gil
C. Patxot 
Costs
A. Frederiksen
E. K. Graversen Germany:

Overtime Work, Dual Job Holding and Taxation 

2000 

A. Ibourk
B. Maillard
S. Perelman
H. R. Sneessens

The Matching Efficiency of Regional Labour

Markets: A Stochastic Production Frontier

Estimation, France 1990-1995 